University of Rhode Island

DigitalCommons@URI

Open Access Master's Theses

1980

\title{
A STUDY ON THE ABILITY OF PRECURSOR AND ACETYLATED PRODUCT TO REFILL CHOLINERGIC VESICLES INDEPENDENTLY OF THE CYTOPLASM
}

Stephen Harold Nelson

University of Rhode Island

Follow this and additional works at: https://digitalcommons.uri.edu/theses

\section{Recommended Citation}

Nelson, Stephen Harold, "A STUDY ON THE ABILITY OF PRECURSOR AND ACETYLATED PRODUCT TO REFILL CHOLINERGIC VESICLES INDEPENDENTLY OF THE CYTOPLASM" (1980). Open Access Master's Theses. Paper 212.

https://digitalcommons.uri.edu/theses/212

This Thesis is brought to you for free and open access by DigitalCommons@URI. It has been accepted for inclusion in Open Access Master's Theses by an authorized administrator of DigitalCommons@URI. For more information, please contact digitalcommons-group@uri.edu. 


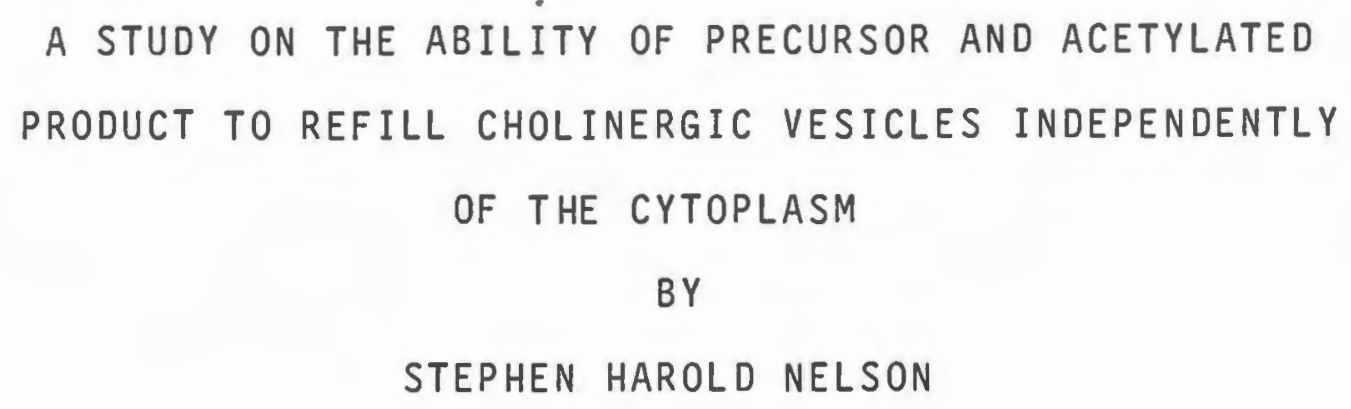

A STUDY ON THE ABILITY OF PRECURSOR AND ACETYLATED PRODUCT TO REFILL CHOLINERGIC VESICLES INDEPENDENTLY OF THE CYTOPLASM

BY

STEPHEN HAROLD NELSON

A THESIS SUBMITTED IN PARTIAL FULFILLMENT OF THE REQUIREMENTS FOR THE DEGREE OF MASTER OF SCIENCE

IN

PHARMACOLOGY AND TOXICOLOGY

UNIVERSITY OF RHODE ISLAND

1980 


\title{
MASTER OF SCIENCE THESIS \\ OF
}

\author{
STEPHEN HAROLD NELSON
}

\section{Approved:}

Thesis Committee

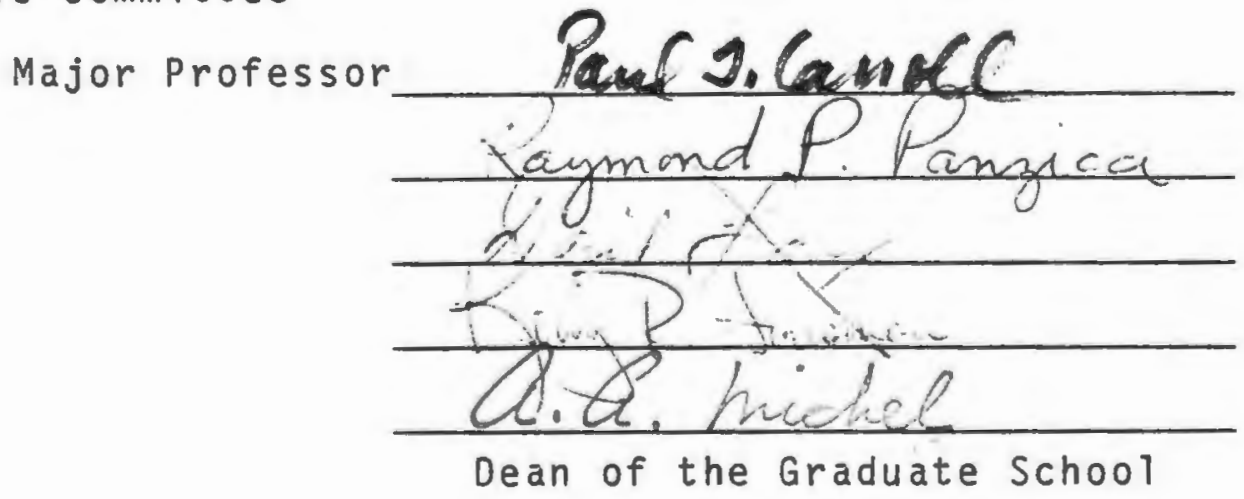

UNIVERSITY OF RHODE ISLAND 


\section{ABSTRACT}

Mouse forebrain minces were incubated in a Krebs or a lithium high $\mathrm{K}+\left(\right.$ L.K.) Krebs medium, cytoplasmic $\left(S_{3}\right)$ and crude vesicular $\left(P_{3}\right)$ fractions prepared and the levels of choline and acetylcholine $(A C h)$ in each, determined. $A C h$ levels were depleted by $70 \%$ in the $P_{3}$ fraction of L.K. Krebs as compared to Krebs, incubated minces; while, $S_{3} A C h$ levels were not significantly altered by the lithium incubation. Lithium treatment lowered the $S_{3}$ choline content by $29 \%$, with no significant effect upon $P_{3}$ choline levels, when compared to $S_{3}$ and $P_{3}$ fractions of contralateral minces incubated in Krebs media. Minces, depleted of $P_{3} A C h$, were subsequentiy incubated in Krebs containing paraoxon $(0.14 \mathrm{M})$ and $0.1 \mathrm{mN}$ concentrations of either ${ }^{14} \mathrm{C}$ choline or ${ }^{14} \mathrm{C}$ homocholine. Depletion of $P_{3} A C h$ resulted in an enhanced transport of extracellular ${ }^{14} \mathrm{C}$ choline $(84 \%)$ and ${ }^{14} \mathrm{C}$ homocholine $(76 \%)$, into this fraction but not into the $S_{3}$ fraction. Furthermore, the depleted $P_{3}$ fraction was repleted with newly synthesized ${ }^{14} \mathrm{C}$ $\mathrm{ACh}$ or ${ }^{14} \mathrm{C}$ acetylhomocholine $\left({ }^{14} \mathrm{C} \mathrm{AHC}\right)$. The ratio of ${ }^{14} \mathrm{C}$ $A C h$ to the total $A C h$ in the repleted $P_{3}$ fraction (0.63), exceeded that attained in the $\mathrm{S}_{3}$ fraction, (0.35). Additionally, the ratio of ${ }^{14} \mathrm{C} A H C$ to $A C h$ in the repleted $P_{3}$ fraction (7.26), was greater than that attained in the $S_{3}$ fraction (0.44). Similar results were obtained when mouse brain hippocampal minces were depleted of $\mathrm{P}_{3} \mathrm{ACh}$ and subsequently 
incubated in krebs containing ${ }^{14} \mathrm{C}$ homocholine $(0.1 \mathrm{mM})$. The ratio of ${ }^{14} \mathrm{C} A H C$ to $A C h$ in the repleted $P_{3}$ fraction $(1.50)$, exceeded that ratio attained in the $S_{3}$ fraction. Incubation of depleted forebrain minces in Krebs containing the preformed products ${ }^{14} \mathrm{C} \mathrm{ACh}$ or ${ }^{14} \mathrm{C} \mathrm{AHC}$, in $0.1 \mathrm{mM}$ concentrations, did not result in an increased transport, or the repletion of the $P_{3}$ fraction with labelled product. However, depletion of $P_{3} A C h$ in hippocampal minces, did result in a greater accumulation of preformed ${ }^{14} \mathrm{C}$ AHC into the repleted fraction, resulting in a higher ratio of ${ }^{14} \mathrm{C} A H C$ to $\mathrm{ACh}$ in the repleted $P_{3}$ fraction $(0.17)$, as compared to the $P_{3}$ fraction of nondepleted minces, $(0.11)$. The amount of preformed ${ }^{14} \mathrm{C}$ AHc transported into the repleted $P_{3}$ fraction was insufficient, however, to replace lost transmitter. These results indicate that depletion of $P_{3}$ transmitter stores, occurs independently of the cytoplasm with newly synthesized product formed from extraceliular precursor. 
TO MY PARENTS

FOR THEIR CONSTANT SUPPORT AND ENCOURAGEMENT 


\section{ACKNOWLEDGEMENTS}

The author wishes to express his appreciation to Dr. Paul T. Carroll for the guidance and encouragement throughout this study. Additionally, I would like to thank Dr. Raymond Panzica and other members of the Department of Medicinal Chemistry for help and advice on the synthesis of the labelled compound acetylhomocholine. 
TABLE OF CONTENTS

ABSTRACT $\ldots \ldots \ldots \ldots \ldots \ldots \ldots \ldots \ldots \ldots \ldots \ldots \ldots \ldots \ldots \ldots \ldots \ldots \ldots \ldots \ldots$

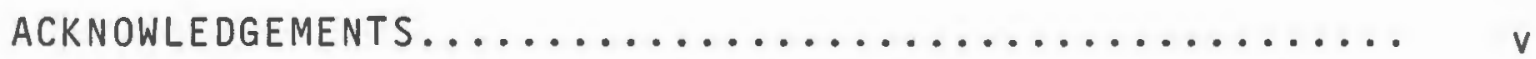

TABLE OF CONTENTS.......................... vi

LIST OF TABLES.......................... viii

LIST OF FIGURES ......................... ix

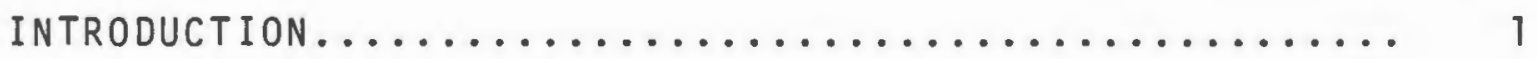

LITERATURE REVIEW......................... 7

Neuronal Pools of ACh........................ 7

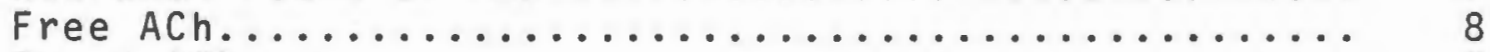

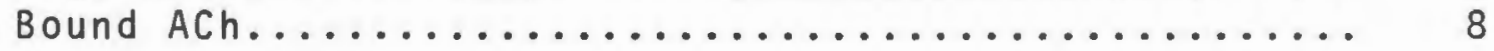

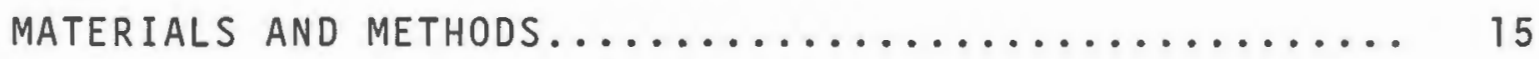

Incubation of Brain Tissue.................. 15

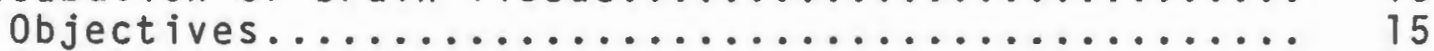

Incubation Media........................ 16

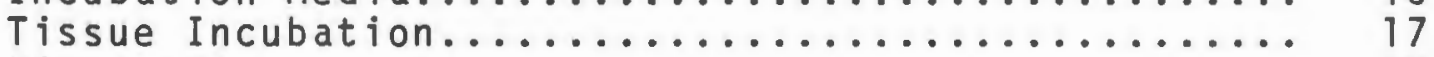

Hippocampus.......................... 19

Subcellular Fractionation Protocol.............. 20

Total Radiolabel Uptake..................... 21

Determination of Tissue $A C h$ and $A H C \ldots \ldots \ldots \ldots \ldots . \ldots 22$

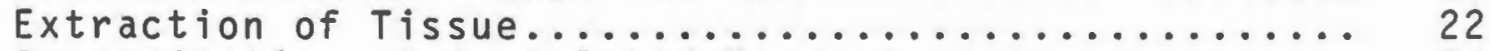

Determination of Acetylated Product............. 24

Cinversion of Precursor to Product.............. 25

Synthes is of Homocholine Iodide.............. 27

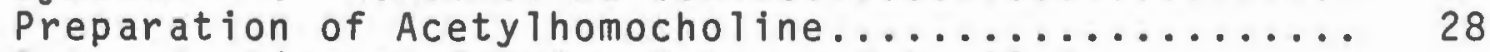

Determination of Overlap Between Subcellular

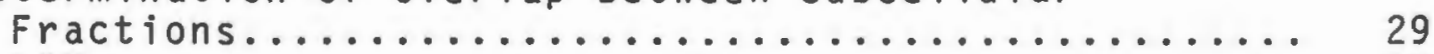

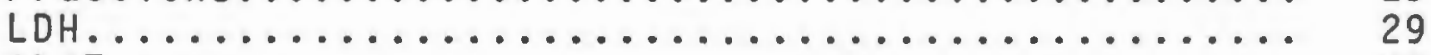

ChAT............................. 30

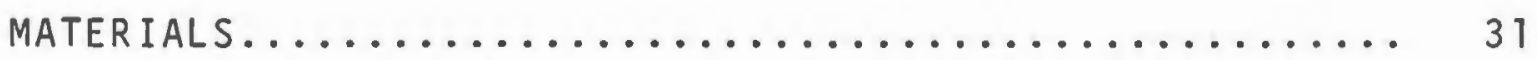

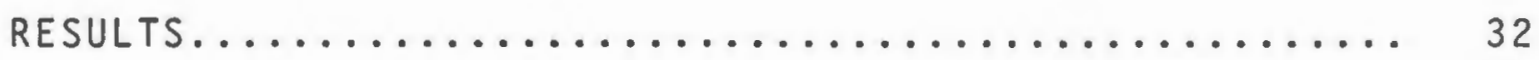

Alteration of Nerve Ending Choline and ACh Levels

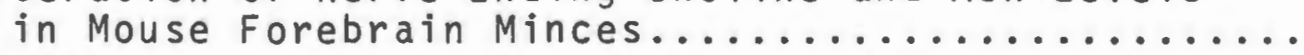

Ability of Extracellular Choline to Refill A

Vesicle-Bound Transmitter Pool with Newly

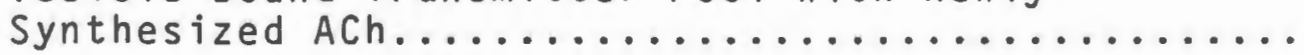


Repletion of the $P_{3}$ Fraction with Newly Synthesized Acetylhomocholine Derived from the Extracellular

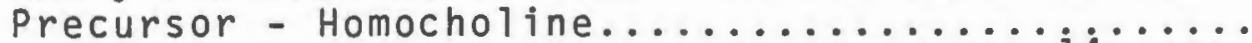

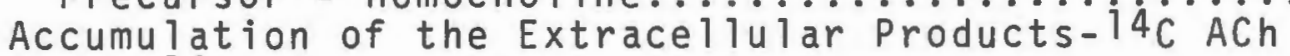
and $14 \mathrm{C} \mathrm{AHC}$ by the $\mathrm{S}_{3}$ and $\mathrm{P}_{3}$ Compartments........

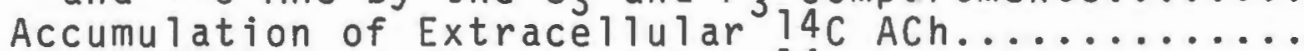
Accumulation of Extracellular 14C AHC.............. Depletion of $\mathrm{P}_{3} \mathrm{ACh}$ and its Effects on the

Transport of Extracellular Precurors and

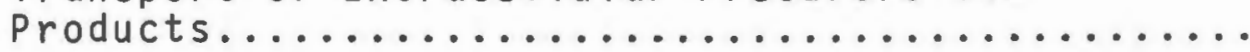

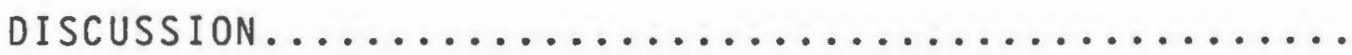

CONCLUSION

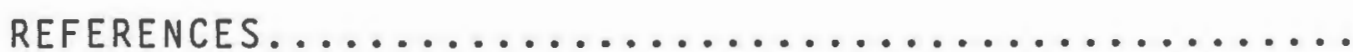




\section{LIST OF TABLES}

TABLE

PAGE

I Differential Effect of L.K. Krebs Treatment on the Acetylcholine Content of $\mathrm{S}_{3}$ and $\mathrm{P}_{3}$ Fractions.

II Differential Effect of Lithium Low $\mathrm{K}^{+}$Krebs Treatment on the Acetylcholine Content of $\mathrm{S}_{3}$

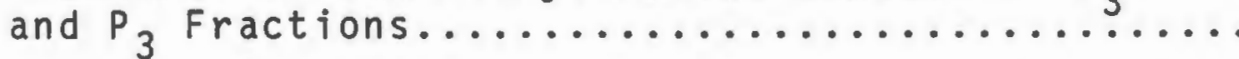

II Differential Effect of L.K. Krebs Treatment on the Choline Content of $\mathrm{S}_{3}$ and $\mathrm{P}_{3}$ Fractions........

IV Ability of a Depleted $P_{3}$ Fraction to be Refilled with Newly Synthesized ACh or AHC Independently

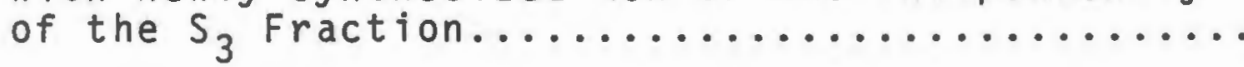

$\checkmark$ Accumulation and Acetylation of Choline and Homocholine by Subcellular Fractions of Mouse

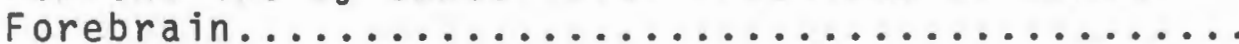

VI Ability of a Depleted $\mathrm{P}_{3}$ Fraction of Forebrain Minces to Accumulate the Preformed Acetylated Products $14 \mathrm{C}$ ACh or $14 \mathrm{C} A H C \ldots . . . . . . . . . .$.

VII Differential Effect of L.K. Krebs Pretreatment on the Movement of Extracellular Precursors$14 \mathrm{C}$ Choline, or $14 \mathrm{C}$ Homocholine and Acetylated products $-{ }^{14} \mathrm{C} \mathrm{ACh}$ and ${ }^{4} \mathrm{C} A H C$, into the $\mathrm{S}_{3}$

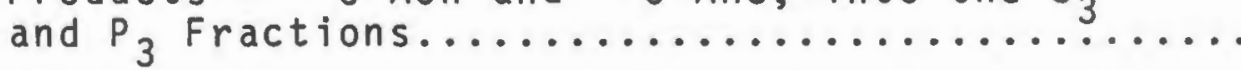

VII Ability of a Depleted $\mathrm{P}_{3}$ Fraction of Hippocampal Minces to be Repleted with Acetylhomocholine Formed from Extracellular Homocholine

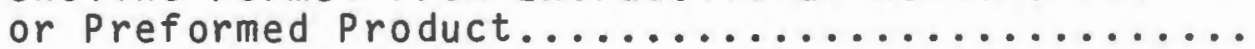




\section{LIST OF FIGURES}

F I GURE

I Subcellular Fractionation Scheme of Brain

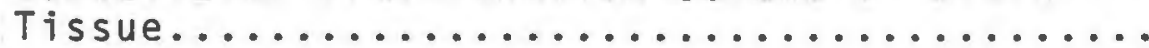

I I Incubation in $\mathrm{N}$. Krebs with $100 \mathrm{uM}{ }^{14} \mathrm{C}$ Cho-

line After Preincubation in $N$. Krebs or

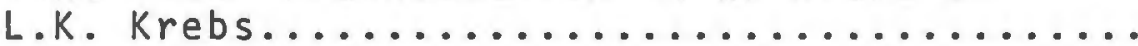

II Incubation in N. Krebs with $100 u M{ }^{14} \mathrm{C}$ Homocholine Subsequent to Incubation in $N$. Krebs

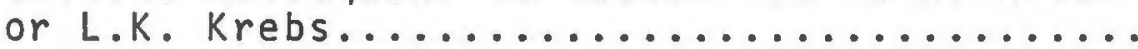

IV Incubation in $\mathrm{N}$. Krebs with $100 \mathrm{uM}{ }^{14} \mathrm{C} \mathrm{ACh}$ Subsequent to Incubation in $N$. Krebs or

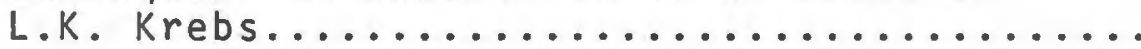

$\checkmark$ Incubation in $N$. Krebs with $100 \mathrm{uM}{ }^{14} \mathrm{C} \mathrm{AHC}$ Subsequent to Incubation in $N$. Krebs or

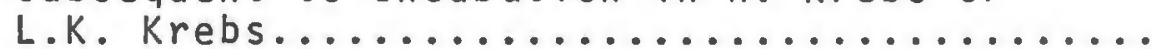




\section{INTRODUCTION}

The majority of acetylcholine, in brain tissue, is 10cated within the nerve terminals of cholinergic neurons (Hebb and Whittaker, 1958; Gray and Whittaker, 1962). Acetylcholine $(A C h)$ is synthesized by the enzyme choline-0-acetyltransferase (ChAT; E.C. 2.3.1.6.), from the precursor choline and acetyl-coenzyme $A$ (Hebb, 1972) and, similar to ACh, the enzyme is primarily found within cholinergic nerve endings (Hebb and Smallman, 1956). The subcellular localization of nerve ending $A C h$ and ChAT has been studied extensively, and there is general agreement that the former is bimodally distributed between the cytoplasm and synaptic vesicles (De Robertis et al., 1963; Whittaker et al., 1964; Whittaker and Sheridan, 1965). In vitro, ChAT also appears bimodally distributed, existing in a soluble and a membrane associated form (Whittaker et al., 1964). The significance of the latter form, in vivo, has been the subject of much controversy.

The development of a unified model, mechanistically depicting ACh metabolism, requires the characterization of precursor uptake and neurotransmitter synthesis, storage and release. According to the current model, all $\mathrm{ACh}$ is synthesized by cytoplasmic ChAT and subsequently transported into synaptic vesicles (Fonnum, 1968, 1970). Fonnum (1967, 1968) has reported that in vitro, as much as $85 \%$ of the total nerve terminal ChAT can be solubilized by high ionic strength media, 
the remainder being associated nonionically with membrane components of the terminal. Thus, given similar in vivo conditions, the majority of ChAT may be cytoplasmic, suggesting that the bulk of ACh synthesis occurs here and that little physiologically significant synthesis occurs elsewhere.

ACh, formed in the cytoplasm, is believed to be translocated into synaptic vesicles (Whittaker, 1959) where upon depolarization all release is said to originate in a $\mathrm{Ca}^{2+}$ dependent manner (del Castillo and Katz, 1954, 1955, 1957; Hebb, 1972; Fonnum, 1973). The current hypothes is places little importance, in terms of maintaining releasable stores of ACh, upon the membrane associated enzyme. Essentially, according to this model, the vesicles are entirely dependent upon the cytoplasm as a source of releasable transmitter. In turn, the enzyme activity of cytoplasmic ChAT is dependent upon the existing vesicular transmitter levels. Thus the two compartments are envisioned as operating in unison and as being interdependent.

Recent investigations have provided evidence that certain aspects of the present model require some modification. That all ACh is synthesized by cytoplasmic ChAT has been questioned on the basis of the observations of Hattori et al. (1976) and Feiganson and Barnett (1977), that ChAT also appears adsorbed to the outer vesicle membrane and possibly contained within the vesicles (Hattori et al., 1976). Others (Haubrich and Chippendale, 1977) have reported that ChAT may be associated with the neuronal membrane, possibly near the 
vesicular attachment sites. Smith and Carroll (1980) have demonstrated enzyme activity in a crude vesicular fraction capable of acetylating choline and certain choline analogs. The authors have suggested that membrane associated ChAT is capable of maintaining vesicular transmitter levels.

Furthermore, investigations characterizing the release mechanism of $A C h$, have indicated that both compartments may function independently of each other. Release of $A C h$, both centrally and peripherally, is believed to occur in two ways-spontaneously and by depolarization (Somogyi and Szerb, 1972; Grewal and Quaste1, 1973; Carroll and Goldberg, 1975). Spontaneous release of ACh originates from the cytoplasm of nerve terminals (Carroll and Goldberg, 1976), occurs during and in the absence of depolarization and does not require extracellular choline or $\mathrm{Ca}^{2+}$. In contrast the depolarized release of transmitter is dependent upon both extracellular choline and $\mathrm{Ca}^{2+}$, exceeds the amount released spontaneously, and appears to originate from the vesicles (Carroll and Goldberg, 1976).

Several investigators have attempted to ascertain the origin of vesicular $A C h$ by measuring the specific radioactivities (sp. act.) of ACh in the two subcellular compartments after incubating tissue in media containing labelled choline. Essentially, if transmitter, stored in synaptic vesicles, is ultimately derived from the cytoplasm, the sp. act. of $A C h$ in the latter compartment should be equal to or exceed that measured in the vesicles. 
Marchbanks (1969), Marchbanks and Israel (1972) and Richter and Marchbanks (1971), using in vitro tissue preparations, have reported that most newly synthesized $A C h$ formed from extracellular choline, appeared in the cytoplasm relative to the vesicles resulting in a greater sp. act. in the former compartment. Similar qualitative results were reported by Chakrin and Whittaker (1969) after injecting 1abelled choline into the cerebral cortex of anesthesized animals.

Systemic administration of labelled choline results in the synthesis of labelled $A C h$ in brain tissue (schuberth et al., 1969, 1970; Jenden et al., 1974). However, different from the results reported above, the sp. act. found in the vesicular fraction was higher than that attained in the cytoplasm (Aquilonious et al., 1973; Schuberth et al., 1969, 1970), indicating that newly synthesized and not preformed ACh can refill vesicular stores of transmitter.

Katz et al. (1973), found that accumulation of preformed labelled ACh did not differ between stimulated and nonstimulated tissue and that stimulation of tissue after preloading with labelled $A C h$ released only unlabelled transmitter. Furthermore, prolonged stimulation in media containing no added choline resulted in lowering total ACh levels. These results suggest that preformed $A C h$ does not replenish reduced stores of transmitter, despite the fact that labelled ACh was accumulated by the nerve endings. Lastly, prepara- 
tions of isolated vesicles, containing endogenous ACh (Marchbanks, 1968) and depleted of vesicular contents (Suskiw, 1976), have failed to accumulate preformed labelled ACh above diffusional levels, suggesting that the active transport of cytoplasmic ACh into vesicles does not occur.

The purpose of this study was to examine the ability of vesicles to refill independently of the cytoplasm and to determine whether only newly synthesized $A C h$, formed from extraceliular choline can refill a depleted vesicular pool of transmitter. The influence of ACh levels, presynaptically, upon stimulation of precursor or preformed product uptake as suggested by Jenden et al. (1976), was also determined. The present investigation differed in an important way from previous studies in that vesicular levels of $A C h$, within intact nerve terminals of forebrain minces, were depleted, thus placing this compartment in a state of required transmitter synthesis prior to exposure to labelled precursor or acetylated product. Depietion of vesicular $A C h$ was attained by incubating brain minces in a lithium containing incubation medium essentially as described by Carroll and Nelson (1978). The nature of vesicular refilling was further examined using the choline and ACh analogs - homocholine and acetylhomocholine, respectively. According to Barker and Mittag (1975) and Collier et al. (1977a, b), homocholine is not acetylated by cytoplasmic ChAT in vitro even though in the latter studies homocholine was taken up by rat brain 
6

synaptosomes and the cat superior cervical ganglion, a percentage of which was acetylated. Release of the acetylated analog was also demonstrated from the ganglionic tissue by a $\mathrm{Ca}^{2+}$-dependent process. Thus if vesicles, previously deplated of $\mathrm{ACh}$, could be refilled with newly synthesized acetylhomocholine, it would further suggest that a vesicular refilling process operates independently of the cytoplasm.

The significance of the present study is that if vediclar stores of transmitter can be refilled, as well as deplated, independently of the cytoplasm, the vesicles and the cytoplasm may represent two physiologically, as well as morphologically, separate compartments. 


\section{LITERATURE REVIEW}

Differential centrifugation of brain tissue which has been homogenized in iso-osmotic media, led to the observation that acetylcholine $(A C h)$ is nonhomogeneously distributed within a cholinergic neuron (Hebb and Whittaker, 1958; Whittaker, 1959). Whittaker et al. (1964), using sucrose density gradient centrifugation, have defined several distinct pools of $A C h$ in central neuronal tissue. The physiological significance of sequestering this transmitter into subcellular compartments has yet to be established, but suggests a separate role for each pool. Two of the most common questions asked regarding neurotransmitter compartmentation are - to what extent, and in what way are these pools interdependent?

The degree of interdependence is of pharmacological import. Several neural disorders, such as Huntington's chorea (Eckernas et al., 1977) and tardive dyskinesia (Davis et al., 1975), have been associated with central cholinergic pathways. If the processes of ACh synthesis, storage and release occur separately within each compartment, then each transmitter pool may be differentially effected by disease processes.

Neuronal Pools of $A C h$

Neuronal $A C h$ can be separated into three pools by 
differential centrifugation of-brain homogenates in iso-osmotic media (Hebb and Whittaker, 1958; Whittaker, 1959; Whittaker et al., 1964; see Fig. 1).

\section{Free $A C h$}

Homogenization of brain tissue in $0.32 \mathrm{M}$ sucrose, liberates a soluble ACh containing fraction $\left(S_{1}\right)$, not bound by membranes and referred to as "free" ACh. This fraction, derived primarily from that ACh originally contained within axons, represents $20-30 \%$ of the total tissue ACh store and requires a cholinesterase inhibitor present during homogenization to protect it from hydrolys is by acetylcholinesterase (AChE; E.C. 3.1.1.7). Free $A C h$ is thought to be formed by ChAT being transported from the cell body to the nerve terminals. At present no physiological function has been attached to this transmitter pool.

\section{Bound $\mathrm{ACh}$}

Separation of the $S_{1}$ fraction at $17,000 \mathrm{~g}$ gives rise to a pellet ( $\mathrm{P}_{2}$ in Fig. 1), referred to as the crude mitochondrial fraction. Distribution studies by Hebb and Whittaker (1958), Whittaker (1959), and later by Gray and Whittaker (1962), demonstrated that $70-80 \%$ of tissue $A C h$ is localized within this fraction. Microscopic analysis of this pellet has revealed that it consists of mitochondria and pinched off nerve endings formed during the initial homogenization of tissue in iso-osmotic (0.32M) sucrose. In such media, 
the nerve endings become resealed and form membranous sacks which Whittaker et al. (1964) have termed synaptosomes. Synaptosomes retain the original component organelles of the intact nerve terminal and thus are metabolically active (Bradford, 1969). Purification of the $\mathrm{P}_{2}$ fraction on discontinuous sucrose density gradients showed that essentially all of the $\mathrm{P}_{2} A C h$ was recovered in the synaptosomal fraction (Marchbanks, 1966) and that little ACh was associated with mitochondria of this fraction.

When the synaptosomal pellet is resuspended in hypoosmotic media and homogenized, the synaptosomal cytoplasm is liberated along with other nerve ending organelles. High speed centrifugation of the synaptosomal homogenate produces a soluble fraction $\left(S_{3}\right)$ corresponding to the nerve terminal cytoplasm. Whittaker (1959) and Whittaker et al. (1964) found that approximately 50-60\% of the nerve ending $A C h$ was liberated upon rupturing the synaptosomes. The ability to measure brain $A C h$ in the $S_{3}$ fraction depends upon the use of a cholinesterase inhibitor during hypo-osmotic rupture of fraction $P_{2}$ and therefore $S_{3} A C h$ is referred to as " $1 \mathrm{ab}-$ ile-bound" $A C h$. The remaining 40-50\% of synaptosomal $A C h$ is found associated with the high speed pellet $\left(P_{3}\right)$ which consists of small mitochondria, partially disrupted synaptosomes and vesicles. Whittaker et al. (1964) and Whittaker and Sheridan (1965) have demonstrated that $P_{3} A C h$ is contained within the vesicles. 
Much of what is presently understood regarding the sequence of events prior to, during and after release of $A C h$, has been derived from electrophysiological studies at peripheral synapses. Fatt and Katz $(1950,1952)$, observed minute spontaneous fluctuations in membrane potentials (miniature endplate potentials; m.e.p.p. ${ }^{15}$ ) that occurred with a mean frequency of approximately one per second, with a potential of less than $1 \mathrm{mV}$. These m.e.p.p.'s are believed to be the result of ACh release in the form of discrete packets or quanta at the neuromuscular junction (Fatt and Katz, 1952) and probably at central synapses (Katz and Miledi, 1963). Each quantum, consisting of several thousand ACh molecules, has been equated with a m.e.p.p.; however, this relationship is not well established. Inorganic calcium, $\mathrm{Ca}^{2+}$, is required for the quantal release of $A C h$ and its role in neurotransmission has been examined by del Castillo and Katz (1954), Katz and Miledi (1967, 1971) and Miledi (1973). When tissue is depolarized, $\mathrm{Ca}^{2+}$ influx is increased and the quanta are released more frequently, producing an endplate potential (e.p.p.) postsynaptically.

At about the same time that the quantal nature of $A C h$ release was demonstrated, electronmicroscopic analys is of brain tissue (DeRobertis and Bennett, 1954, 1955), and of the neuromuscular junction (Robertson, 1956), demonstrated the existence of synaptic vesicles $(400-500 \AA$ in dia.), concentrated at the presynaptic nerve terminal membrane. These 
vesicles became the structural counterpart of the release mechanism, providing an understanding as to how $A C h$ is released as quanta. Each vesicle, depending upon the animal species used, may consist of as many as 1,500 to 2,000 molecules of ACh (Krnjevic and Phillis, 1963), although a much

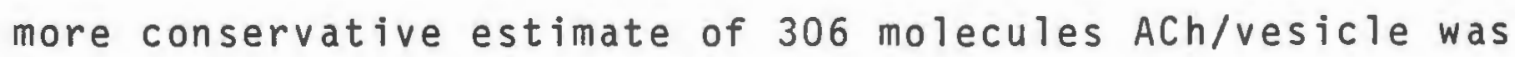
derived by Whittaker and Sheridan (1965); however, the low distribution of cholinergic terminals in the tissue used was not considered by these investigators.

The observations that $A C h$ is released as quanta and that the vesicles are the likely means by which quantal release takes place, gave rise to the vesicle hypothesis of neurotransmission. Essentially, it states that $A C h$ is packaged within nerve terminal vesicles, and upon depolarization and the simultaneous influx of extracellular $\mathrm{CA}^{2+}$, the contents of the vesicles, each of which consists of a quantum of $A C h$, are released into the synapse.

Although the vesicle hypothesis readily offers a plausible explanation as to how the quantal release of transmitter is achieved, there are reports suggesting that quantal release occurs from the cytoplasm. Those proponents of cytoplasmic transmitter release, base much of their argument on the fact that a high proportion of the nerve terminal $A C h$, along with ChAT, is present in the cytoplasm. Israel and Dunant (1975), observed that cytoplasmic ACh levels oscillated when tissue of the electric organ of Torpedo sp. were electrically stimulated. That only cytoplasmic, and not 
vesicular, ACh was shown to oscillate in content, led the authors to conclude that the source of releasable ACh was from the cytoplasmic compartment. However, Israel and Dunant were unable to measure fluctuations in the postsynaptic membrane potential, which is necessary for supporting their hypothesis. Tauc et al. (1974), noted that hydrolysis of cytoplasmic ACh, through microinjection of $A C h E$ into the neuron, reduced the synaptic transmission. However, it was not shown whether any AChE was also incorporated into synaptic vesicle and whether this source of ACh was also significantly depleted.

Israel and Dunant (1975), reported that after stimulation of the electric organ of Torpedo sp., at $10 \mathrm{~Hz}$ for 5-10 minutes, cytoplasmic $A C h$, but not vesicular transmitter, was lowered. However, several others, including Zimmerman and Whittaker (1974), have indicated that both vesicular content of $A C h$, and vesicle numbers, were diminished upon continuous electrical stimulation of the electric organ, indicating that the vesicles are the source of transmitter release. A problem associated with this conclusion is that the correlation between the recovery of vesicle number and the return of normal synaptic transmission is unclear. Often, neurotransmission recovers from fatigue before the vesicle population returns to pre-stimulatory levels. However, Heuser and Reese (1978), have suggested that not all of the vesicles observed in electron micrographs contain releasable transmitter and thus it would depend upon the percent of the original vesicle 
population that was present at any given time after stimulation (Heuser, 1978). These investigators have further reported evidence, obtained through freeze fracturing techniques supporting an exocytotic-endocytotic release cycle. Actual membrane alterations (indentation) have been observed where synaptic vesicles are believed to have fused with the neuronal membrane and released their contents. Excitation of such tissue in the absence of $\mathrm{Ca}^{2+}$, which is necessary for quantal release (del Castillo and Katz, 1954), results in a lack of these membrane indentations.

Fractionation of brain (Barker et al., 1972) and electric organ (Zimmerman and Denston, 1977) by differential and sucrose gradient centrifugation, has led to the separation of two metabolically distinct vesicle populations; a less dense monodispersed fraction ( $D$ or $V P_{1}$ ) and a fraction in close association with the neuronal membrane (H). Incubation of tissue in the presence of labelled choline (Barker et al., 1972) or the analog-homocholine (von Schwartztenfeld, 1979) results in newly synthesized transmitter of high specific activity (sp. act.), found primarily within the vesicles in closest association to the neuronal membrane. Labelling of presynaptic stores of transmitter with subsequent stimulation of the tissue, release preferentially, newly synthesized transmitter (or false transmitter), with a sp. act. similar to the sp. act. associated with fraction $H$ vesicles, and higher than that measured in the cytoplasm or monodispersed vesicles (Suskiw et al., 1978; von Schwarzenfeld, 
1979). The preferential release of newly synthesized transmitter has also been shown by Collier (1969), using the cat superior cervical ganglion.

A question that remains unresolved is that if $A C h$ is synthesized in the cytoplasm and released from vesicles as quanta, by what mechanism is the transmitter concentrated within the latter structures. Presently, no firm biochemical evidence exists that supports the concept of ACh mobilization into depleted vesicle stores, above diffusional levels. It was the purpose of this study therefore, to examine whether vesicles, depleted of $A C h$, are refilled with preformed transmitter, derived from the cytoplasm, or are repleted with newly formed transmitter derived from extracellular precursors. 


\section{MATERIALS AND METHODS}

Male (CD-1) albino mice were killed by cervical dislocation in the cold $\left(4^{\circ}\right)$. The brains (minus the pons, medulla and cerebellum) were sectioned through the median sagittal fissure and each hemisphere washed in ice cold normal krebs or lithium Krebs media (media described below), to remove extracellular choline and AChE. A characteristic postmortem elevation of brain choline levels, which can alter the rate of ACh metabolism has been reported by several investigators (Schuberth, 1966; Schuberth et al., 1970; Dross and Kewitz, 1972; Nordberg, 1977). Washing the brains in ice cold media minimizes this effect. The forebrains were then blotted dry, weighed, minced and placed on a chilled petri dish until the onset of incubation.

Incubation of Brain Tissue

Objectives

Tissue incubations were routinely conducted at $37-38^{\circ}$ under $95 \%_{2}-5 \% \mathrm{CO}_{2}$ in a Dubnoff Metabolic Shaker set at 90 cycles/min. The overall design of the tissue incubations, as described below, was to: 1) selectively reduce the $A C h$ content of the vesicle-bound pool without altering cytoplasmic ACh levels; 2) determine whether the reduced vesiclebound pool could be refilled with newly synthesized product formed from extracellular precursors and/or with extra. 
cellular preformed (i.e., acetylated) products; and 3 ) determine if the refilling process occurs independently of the cytop lasm.

\section{Incubation Media}

Several investigators (Whittaker et al., 1975; Jenden et al., 1976) have suggested that the amount of extracellular choline taken up presynaptically, is determined by the existing nerve-ending levels of $A C h$. To examine the ability of the vesicle-bound pool to be refilled with newly synthesized or preformed product, minces were preincubated in 10 mls of a nondepolarizing Krebs phosphate buffer medium (composition in $\mathrm{mM} ; \mathrm{NaCl} 117 ; \mathrm{KCl} 3.5 ; \mathrm{KH}_{2} \mathrm{PO}_{4} 1.2 ; \mathrm{CaCl}_{2} 2.5$; $\mathrm{MgSO}_{4} \cdot 7 \mathrm{H}_{2} \mathrm{O} 1.2 ; \mathrm{NaHCO}_{3} 28.0$ and glucose 11.1$)$ while the contralateral minces were similarly preincubated in a lithium Krebs medium, in which $\mathrm{LiCl}(117 \mathrm{mM})$ replaced $\mathrm{NaCl}$ and $\mathrm{KHCO}_{3}$ (25.0 mM) replaced $\mathrm{NaHCO}_{3}$ (see below).

Several investigators have shown that lithium ions depolarize nerve terminals (Schou, 1957; Keynes and Swan, 1959) and by an unestablished mechanism blocks choline uptake presynaptically (Diamond and Kennedy, 1969; Simon and Kuhar, 1976; Jope, 1979). In an initial set of experiments (performed by Dr. P.J. (arroll), incubation of brain minces in a lithium krebs medium, containing $\mathrm{NaHCO}_{3}$, resulted in a $70 \%$ reduction of vesicle-bound $A C h$ relative to contralateral minces incubated in a krebs medium. No significant alteration of cytoplasmic ACh levels occurred as a result of the incubations. 
According to Schou (1957), lithium ions $\left(\mathrm{Li}^{+}\right)$, appear to depress cellular respiration in several tissues (e.g. renal and cardiac tissues). Accordingly, a modified lithium krebs medium was utilized in which $\mathrm{KHCO}_{3}$ replaced $\mathrm{NaHCO}_{3}$ (maintaining ios-osmolarity). Potassium, in concentrations up to 40 $\mathrm{mM}$, is known to stimulate tissue respiration (Canzanelij, 1942) and when added to a lithium medium reverses the lithium-induced depression of respiration. However, it should be pointed out that in brain tissue, $\mathrm{Li}^{+}$concentrations up to $100 \mathrm{mM}$ also stimulate cellular respiration (Canzanelli, 1942).

Incubation of brain minces in lithium krebs containing $\mathrm{NaHCO}_{3}$ or $\mathrm{KHCO}_{3}$ has the same effect on lowering vesicle-bound ACh levels by $70 \%$ independently of the cytoplasm (Carroll and Nelson, 1978) and releases equivalent amounts of $\mathrm{ACh}$ into the incubation media (Nelson et al., 1980), thereby indicating that the inclusion of potassium is not disrupting central ACh metabolism. Therefore, $\mathrm{KHCO}_{3}$ replaced $\mathrm{NaHCO}_{3}$ in all lithium krebs media used, unless otherwise stated. It should also be noted that $\mathrm{Li}^{+}$are unique in that they can replace $\mathrm{Na}^{+}$ in several processes (Schou, 1957) and of particular importance $\mathrm{Li}^{+}$can support ChAT activity whereas the absence of $\mathrm{Na}^{+}$ cannot (Potter et al., 1968).

\section{Tissue Incubation}

Minces were preincubated for a total of 30 minutes in $10 \mathrm{mls}$ of normal Krebs (K.) or lithium $K^{+}$Krebs (L.K.) media. The tissue was centrifuged $\left(1000 \mathrm{~g} ; 4^{\circ}\right)$ and $\mathrm{placed}$ in fresh 
media after the initial 15 minutes to reduce the accumulation of extracellular choline in the media generated primarily from phospholipid turnover (Bhatnagar and Macintosh, 1967; Browning and Schulman, 1968; Browning, 1971; Collier et al., 1972). If the choline levels in the media become sufficiently elevated the lithium-induced inhibition of choline uptake may be partially reversed (although this effect was not examined in this investigation).

Tissue samples were placed on ice at the end of the preincubation, centrifuged $\left(1000 \mathrm{~g}, 4^{\circ}\right)$ and the pellets washed $(2 \times 5 \mathrm{mls})$ with ice cold $K$. media (the second wash contained 0.1 uM paraoxon).

To ascertain whether the vesicle-bound fraction, previously depleted of its $A C h$ content, could be refilled with newly synthesized ACh or acetylhomocholine (AHC) formed from the extracellular precursors $\left[{ }^{14} \mathrm{C}\right]$ choline or $\left[{ }^{14} \mathrm{C}\right]$ homocholine, minces were incubated an additional 30 minutes in 5 $\mathrm{mls}$ of $\mathrm{K}$. containing labelied choline $(0.1 \mathrm{mM})$ or homocholine $(0.1 \mathrm{mM})$ and paraoxon $(0.1 \mathrm{uM})$, (incubation of minces in labelled choline was performed by Dr. P.T. Carroll).

In a similar set of experiments designed to test the ability of preformed product to refill a depleted vesiclebound pool, minces, previously incubated in K. or L. K. media, were subsequently incubated for 30 minutes in $5 \mathrm{mls}$ of $K$. containing $0.1 \mathrm{mM}$ concentrations of $\left[{ }^{14} \mathrm{C}\right] \mathrm{ACh}$ or $\left[{ }^{14} \mathrm{C}\right] \mathrm{AHC}$ and 0.1 UM paraoxon. 
Subsequent to: the 30 minute $K$. incubation in labelled precursor or preformed product, tissue samples were centrifuged $\left(1000 \mathrm{~g} ; 4^{\circ}\right)$, the media discarded and the tissue washed $(2 \times 5 \mathrm{mls})$ with ice cold $0.32 \mathrm{M}$ sucrose.

\section{Hippocampus}

Several investigators have determined that ACh uptake into brain tissue is not specific for cholinergic neurons (Katz et al., 1973; Kuhar and Simon, 1974), suggesting that ACh uptake into central tissues is of little physiological import.

To determine whether an acetylated product could enter the nerve terminals of cholinergic neurons, 10-20 mice were killed, the brains removed and half placed in a $K$. ice cold washing medium and half placed in ice cold L. K. media. The hippocampi of the $K$. Washed brains were removed, pooled and minced on a chilled petri dish while the hippocampi of the L. K. washed brains were similarly prepared. Hippocampal tissue consists of approximately 85-90\% cholinergic nerve terminals (Kuhar et al., 1973). There are two hippocampi per brain, each lying lateral to the median sagittal fissure at the level of the lateral ventricle floor. The hippocampal tissue was incubated in either K. or L. K., as previously described and then washed in ice cold $K$. (second wash containing paraoxon 3 uM). The tissue was then incubated for 30 minutes in $K$. containing $0.1 \mathrm{mM}\left[{ }^{14} \mathrm{C}\right] \mathrm{AHC}$ and 3 UM paraoxon. 
In another set of experiments, hippocampal tissue was similarly prepared and incubated in $K$. containing $0.1 \mathrm{mM}$ $\left[{ }^{14} C\right]$ homocholine plus paraoxon ( 3 UM) to compare the uptake and acetylation characteristics between hippocampal (primarily cholinergic) and forebrain (approximately 15\% cholinergic nerve terminals) tissue.

The tissue minces were then washed $(2 \times 5 \mathrm{mls})$ in ice cold $0.32 \mathrm{M}$ sucrose and prepared for subcellular fractionation.

\section{Subcellular Fractionation Protocol}

Subcellular fractions of minces were prepared according to the method of Gray and Whittaker (1962) as modified by Collier et al. (1972) and Salehmoghaddam and Collier (1976). The washed minces were resuspended in $5 \mathrm{mls}$ of ice cold $0.32 M$ sucrose vortexed and transferred to a teflon to glass homogenizer $(0.025 \mathrm{~cm} \mathrm{clearance})$ set at $840 \mathrm{rpm}$ and homogenized using 8 up and down strokes. The homogenates were transferred to chilled tubes and centrifuged at $1000 \mathrm{~g}$ for 10 minutes. The pellet $\left(P_{1}\right)$, containing nuclear debris, myelin and unbroken cells, was discarded. The supernatant (S1) consisting primarily of mitochondria and synaptosomes, was centrifuged for 15 minutes at $17,000 \mathrm{~g}$. The $S_{2}$ fraction (microsomal fraction) consists of nearly $20 \%$ of the total tissue ACh. The $P_{2}$ fraction (synaptosomal fraction), was resuspended in $2 \mathrm{mls}$ of glass distilled water $(\mathrm{pH} 4.0)$ containing paraoxon ( 0.1 uM) to hypo-osmotically rupture the 
synaptosomes. Paraoxon was included to preserve the labile or cytoplasmic ACh. Subsequent to homogenization in a tefIon to glass homogenizer ( $400 \mathrm{rpm} ; 8$ up and down strokes) the homogenate was centrifuged at $100,000 \mathrm{~g}$ for 90 minutes in chilled tubes.

The resulting crude vesicular pellet $\left(P_{3}\right)$ consists of monodisperse and neuronally associated vesicles. Evidence that the vesicles are not artifacts of the tissue fractionation scheme was derived from experiments in which the cholinesterase inhibitor-paraoxon, was omitted just prior to the initial tissue homogenization. The levels of $P_{3} A C h$ did not differ from tissue homogenates with or without inhibitor, whereas, omission of paraoxon resulted in nondetectable levels of $\mathrm{S}_{3} \mathrm{ACh}$.

The $S_{3}$ supernates were collected and stored at $-20^{\circ}$. After surface washing the $P_{3}$ pellets $(2 \times 8 \mathrm{mls})$ with glass distilled water ( $\mathrm{pH} 4.0$ ), the pellets were transferred to ground glass homogenizers (Duall-20; Thomas Co.) and homogenized in 500 ul ice cold in Formic Acid/Acetone (15/85; $v / v)$ and allowed to set in ice, for 20 minutes. This procedure extracts nearly all tissue $A C h$ and choline (Toru and Aprison, 1966). Subsequent to a $10,000 \mathrm{~g} 20$ minute centrifugation in the cold, an aliquot ( 300 ul) of clear supernate was removed and stored at $-20^{\circ}$. Total Radiolabel Uptake

The total radiolabel uptake of labelied precursor or product into the $S_{3}$ or $P_{3}$ fractions was determined by 
removing 40 ul aliquots of either fraction, adding it to $\mathrm{Hy}$ dromix (15 mls) and counting in a liquid scintillation spectrometer (Packard Model 3330). Counting efficiency was determined by adding $\left[{ }^{14} \mathrm{C}\right]$ toluene standard (20 Ul) to samples. Quenching did not appear to reduce the counting efficiency. Determination of Tissue $A C h$ and $A H C$

Total ACh and AHC levels were determined using the assay method of Goldberg and McCaman (1973). In some cases, a modification of this method was employed where the extraction of tissue samples was omitted.

Extraction of Tissue

According to Goldberg and McCaman (1973) and McCaman and Stetzler (1977), consistent and reliable results derived from the assay described below are attainable only when tissue samples are initially extracted with a liquid cation exchange substance - sodium tetraphenylboron dissolved in 3-heptanone $(T P B / 3 H)$. Using this procedure, Na-TPB exchanges $\mathrm{Na}^{+}$for quaternary species present in the aqueous solution. The resulting amine-TPB complex is insoluble in aqueous, but soluble in organic (e.g., 3-heptanone) solvents.

Cytoplasmic $\left(\mathrm{S}_{3}\right)$ samples were extracted by mixing 300 ul of TPB/3H $(5 \mathrm{mg} / \mathrm{ml})$ with 100 ul of sample. After separating the phases by centrifugation, 200 ul of the organic layer were re-extracted with 100 ul of 1 NHCl and again centrifuged. The organic layer was discarded and 20-25 ul of the aqueous 
phase dried in vacuo for assay. Standards of ACh (200 pmoles; bromide salt) were similarly extracted from 100 ul of water or from one of the incubation media and assayed along with the samples. It should be noted that standards of $A C h B r$, added to $100 \mathrm{ul}$ of $\mathrm{H}_{2} \mathrm{O}, 4.7$ or $35 \mathrm{mMK}^{+} \mathrm{Krebs}$ or L. K. media are extracted equally indicating that the ions present in the media do not inhibit the extraction of $A C h$.

The vesicle-bound $\left(P_{3}\right)$ fraction was extracted by initially drying (in vacuo) $50 \mathrm{ul}$ of the formic acid/acetone tissue extract. Subsequently, 50 ul of $10 \mathrm{mM}$ sodium phosphate buffer ( $\mathrm{pH}$ 6.6) was added to the dried samples and then mixed with 200 ul TPB/3H $(5 \mathrm{mg} / \mathrm{ml})$. One hundred fifty microliters of the organic phase was removed and re-extracted with 75 ul of IN HCl. Again, 20-25 ul of the acid phase was dried in vacuo for assay. Acetylcholine standards (200 pmoles) were similarly extracted and assayed.

For the determination of ACh levels in the $S_{3}$ and $P_{3}$ fractions of tissue incubated in $\left[{ }^{14} C\right]$ choline, $\left[{ }^{14} C\right] A C h$ and one preparation (i.e., 4 brains) using $\left[{ }^{14} C\right]$ AHC, samples were not extracted. Instead, $10 \mathrm{ul}$ of $\mathrm{P}_{3}$ or 10-20 ul of $S_{3}$ sample were dried in vacuo and assayed directly. For one set of experiments, four brains were incubated in $\left[{ }^{14} \mathrm{C}\right]$ homocholine and subcellular fractions prepared as described previously. Comparison of $S_{3}$ values for total acetylated product ( $A C h$ and $A H C$ ), obtained from extracted samples were similar to those of nonextracted samples $(12.4 \pm 1.3 \mathrm{nmoles} / \mathrm{gm}$ tissue and $12.6 \pm 0.9$ nmoles/gm tissue, respectively. 
Additionally, similar total ACh values were obtained for extracted and nonextracted $P_{3}$ samples derived from six brains incubated in $\left[{ }^{14} \mathrm{C}\right]$ choline $(9.3 \pm 1.4 \mathrm{nmoles} / \mathrm{gm}$ wet $\mathrm{wg}$. tissue and $8.8 \pm 1.4$ nmoles/gm wet wgt. tissue, respectively. Thus whether the $S_{3}$ or $P_{3}$ samples, of a given tissue preparation, were extracted initially, or assayed directly, comparison of the values for total acetylated product obtained using either procedure were not significantiy different. Detection of $A C h$ (or $A H C$ ) in nonextracted tissue was linear through 20 ul of $S_{3}$ and 10 ul of $P_{3}$ sample. Also, measurement of ACh is linear when samples equivalent to $2.5 \mathrm{mg}$ tissue or less are used.

Determination of Acetylated Product

Initially, 10 ul of a buffered substrate was added at $0-2^{\circ}$ to each dried sample. The buffer is comprised of, in final concentration within each sample tube, $64 \mathrm{~mm}$ sodium phosphate $(\mathrm{pH} 8.0) ; 0.8 \mathrm{mM} \mathrm{ATP:} 3.1 \mathrm{MgCl}_{2}$ and $1.2 \times 10^{-3}$ units of choline phospholinase (CPK), E.C. 2.7.1.32. During the subsequent incubation of samples at $37-38^{\circ}$, all free choline (or homocholine), is phosphorylated to phosphorylcholine (or phosphorylhomocholine). After placing the samples on ice, 2 ul of a second buffered substrate consisting of $35 \mathrm{mM}$ sodium phosphate ( $\mathrm{pH} 8.0), 0.23$ unit AChE (E.C. 3.1.1.7) and $\left[V-{ }^{32} \mathrm{P}\right]$ ATP, $15-35 \mathrm{Ci} / \mathrm{mmole}$, in final concentrations in assay samples, were added. The samples were incubated an additional 15 minutes during which time $A C h$ or $A H C$ is 
hydrolyzed to choline or homocholine and subsequently phosphorylated to $\left[{ }^{32}\right.$ p $]$ phosphoryl-choline or -homocholine. The reaction was terminated by placing samples in ice water and adding 20 ul of $0.3 \mathrm{M}$ barium acetate to precipitate the unreacted ATP. According to Goldberg and McCaman (1973) this step removes nearly $98 \%$ of the unreacted ATP. After a one minute centrifugation (2500 rpm), an aliquot of supernate was removed and added to anion exchange microcolumns made up of ammonium formate resin (200-400 mesh; medium pore size). This procedure removes the remaining $2 \%$ of unreacted ATP while the phosphorylcholine or phosphorylhomocholine is eluted with 1200 ul of $75 \mathrm{mM}$ ammonium acetate (pH 10.0). Samples were collected and counted in Hydromix $(15 \mathrm{mls})$. Nonextracted external standards (200 pmoles ACh; bromide salt) were similarly assayed along with samples. Additionally, internal standards (100 pmoles $\mathrm{AChBr}$ ) were added to some samples to determine if any tissue inhibition of the assay existed.

\section{Conversion of Precursor to Product}

When minces were incubated in $K$. containing the precursors $\left[{ }^{14} \mathrm{C}\right]$ choline or $\left[{ }^{14} \mathrm{C}\right]$ homocholine, the percent conversion (acetylation) of the total radiolabel uptake was determined by a method as described by Carroll and Goldberg (1975). Using this procedure, $10 u 1$ of $S_{3}$ or $P_{3}$ (FA/A) samples were dried in vacuo and 10 ul of a buffered substrate, at $0-2^{\circ}$, added. This medium consisted of, in final 
sample concentrations, $70.3 \mathrm{mM}$ sodium phosphate buffer ( $\mathrm{pH}$ $8.0) ; 1.2 \mathrm{mM} \mathrm{ATP} ; \mathrm{Y}-{ }^{32} \mathrm{P}$ ATP, $15-35 \mathrm{Ci} / \mathrm{mmole} 2.3 \mathrm{mM} \mathrm{MgCl} 2$ and $7.03 \times 10^{-4}$ unit of CPK. Samples were incubated at $37-38^{\circ}$ for 15 minutes during which time all nonmetabolized (free) choline or homocholine is converted to the phosphorylated species. The samples were set at $0-2^{\circ}$ in an ice bath and extracted by initially adding 25 ul of water followed by 150 ul of $T P B / 3 H(75 \mathrm{mg} / \mathrm{m} 1)$. This process extracts the acetylated positively charged species ( $A C h$ and $A H C$ ) while the negatively charged phosphorylated species (phosphorylcholine and phosphorylhomocholine) remain in the aqueous phase. The conversion of the precursors choline and homocholine to the phosphorylated forms is essentially $100 \%$ over a concentration range of 5-1000 pmoles. Additionally, extraction of each precursor from an aqueous medium with TPB/3H $(75 \mathrm{mg} / \mathrm{ml})$ is complete and linear throughout this same concentration range. After separation of the phases by centrifugation, 100 ul of the organic layer and 10 ul of the aqueous phase are counted in 10-15 $\mathrm{mls}$ Hydromix. The activity in the organic phase represents newly synthesized product, $\left[{ }^{14} \mathrm{C}\right] \mathrm{ACh}$ or $\left[{ }^{14} \mathrm{C}\right] \mathrm{AHC}$, while the activity in the aqueous phase represents the $\left[{ }^{14} \mathrm{C}\right]$ choline or $\left[{ }^{14} \mathrm{C}\right]$ homocholine that was not metabolized (acetylated) during the tissue incubation. Additionally, the activity expressed within the aqueous phase of the assay sample was considered as that labelled choline or homocholine not phosphorylated endogenously by neuronal 
CPK and ATP during tissue incubation with precursor. To determine whether the nonacetylated precursor present within the tissue was in fact free (i.e., nonphosphorylated) base, minces were preincubated in $K$. or $L$. $K$. with subsequent incubation in $K$. containing $\left[{ }^{14} \mathrm{C}\right]$ choline $(0.1 \mathrm{mM})$, or $\left[{ }^{14} \mathrm{C}\right]$ homocholine (0.1mM) and paraoxon (0.1uM). Subcellular fractions were prepared and the $S_{3}$ and $P_{3}$ samples assayed for newly synthesized product and precursor as described above with the exception that CPK and ATP were not incorporated into the assay. The amount of radiolabel remaining in the aqueous phase indicates the amount of endogenous phosphorylation of precursor occurring during the incubation with the labelied precursors.

\section{Synthesis of Homocholine Iodide}

Unlabelled methy iodide $(1.5 \mathrm{ml} ; 24.1 \mathrm{mmoles})$ was added to 3-dimethylamino-1-propanol (3.5 ml; 29. mmoles) immediately producing a white precipitate. The solid was washed $(2 \times 10 \mathrm{ml})$ with anhydrous ether and centrifuged in the cold $\left(4^{\circ}\right)$ at $3,500 \mathrm{rpm}$. The supernatants were decanted and the product-homocholine iodide, was dried in vacuo. The reaction afforded $5.61 \mathrm{~g}(95 \%)$ homocholine iodide with the following physical characteristics: m.p. 196-198.5: pmr $\left.\left(\mathrm{DMSO}_{-\mathrm{d}_{6}}\right) 4.75 \odot, 1, \mathrm{~J}=5 \mathrm{~Hz}, \mathrm{OH}\right), 3.49\left(\mathrm{~m}, 4-\mathrm{CH}_{2}-\mathrm{CH}_{2}-\mathrm{CH}_{2}-\right.$ ), $3.14\left(\mathrm{~s}, 9, \stackrel{+}{\mathrm{N}}\left(\mathrm{CH}_{3}\right)_{3}\right), 1.92\left(\mathrm{p}, 2,-\mathrm{CH}_{2}-\underline{\mathrm{CH}}_{2}-\mathrm{CH}_{2}-\right) . \mathrm{N}-\left[\mathrm{Me}{ }^{14} \mathrm{C}\right]$ homocholine iodide was synthesized as described above with the exception that 2 ul of $\left[{ }^{14} \mathrm{C}\right] \mathrm{CH}_{3}$ I were diluted with $20 \mathrm{ul}$ 
of unlabelled $\mathrm{CH}_{3}$ I to a final specific activity of $4.85 \mathrm{mCi} /$ mmole. The washed product was dissolved in $10 \mathrm{ml}$ of distilled water ( $\mathrm{pH} 6.5$ ) to give a final concentration of $8.04 \mathrm{mM}$ and stored at $-20^{\circ}$.

\section{Preparation of Acetylhomocholine Iodide}

Homocholine iodide $(2.0 \mathrm{gm} ; 8.2 \mathrm{mmoles})$, produced as described above, was refluxed with $20 \mathrm{ml}$ of acetic anhydride while stirring under an atmosphere of $\mathrm{N}_{2}(\mathrm{~g})$ according to the method of waltz et al. (1951). The excess anhydride was removed under reduced pressure and heat, producing a colored precipitate. The solid was washed $(2 \times 10 \mathrm{ml})$ with anhydrous ether and recrystallized by dissolving it in a minimum amount of absolute ethanol and bringing the solution to the cloud point with anhydrous ether. After washing the precipitate with anhydrous ether, the product was dried in vacuo over $\mathrm{P}_{2} \mathrm{O}_{5}$ for 24 hrs. providing $2.15 \mathrm{~g}(91.5 \%)$ of acetylhomocholine iodide with the following physical characteristics: m.p. 96-97.5०; pmr (DMSO-d $)^{\circ}$ ) $4.12\left(t, 2, J=6 \mathrm{~Hz}^{\circ}-\mathrm{CH}_{2}-\mathrm{CH}_{2} \mathrm{O}-\right.$ ), 3.51 $\left(\mathrm{m}, 2,\left(\mathrm{CH}_{3}\right) \mathrm{N}-\mathrm{CH}_{2}-\mathrm{CH}_{2}-\right) 3.17\left(\mathrm{~s}, 9, \stackrel{+}{\mathrm{N}}\left(\mathrm{CH}_{3}\right)_{3}\right), 2.07(\mathrm{~s}, 3$, $\left.0-\mathrm{CH}_{2}-\mathrm{CH}_{2}\right), 2.07\left(p, 2,-\mathrm{CH}_{2}-\mathrm{CH}_{2}-\mathrm{CH}_{2}-\right)$.

Anal. Calcd. for $\mathrm{C}_{8} \mathrm{H}_{18} \mathrm{NO}_{2} \mathrm{I}$ : C, 33.46; $\mathrm{H}, 6.32 ; \mathrm{N}, 4.88$. Found: $\quad C, 33.29 ; H, 6.16 ; \mathrm{N}, 5.01$.

$\mathrm{N}-\left[\mathrm{Me}-{ }^{14} \mathrm{C}\right]$ acetylhomocholine iodide was similarly sunthesized with the exception that the specific activity of the undiluted methyl iodide was $49.0 \mathrm{MCi} / m m o l e . ~ A d d i t i o n a l l y$, the final recrystallized product was dried by a stream of 
dried $\left(\mathrm{H}_{2} \mathrm{SO}_{4}\right) \mathrm{N}_{2}(\mathrm{~g})$. The product was dissolved in distilled water ( $\mathrm{pH}$ 6.5) and stored at $-20^{\circ}$. The final specific activity of the product was $5.42 \mathrm{mC} / \mathrm{mmole}$.

Melting points were determined with a Thomas-Hoover apparatus and are uncorrected. The proton magnetic resonance spectra were obtained on a Varian A-60 spectrometer using TMS as an internal standard. Descending paper chromatography with a solvent system of n-butanol-absolute ethanol-1N acetic acid-water $(8: 2: 1: 3)$ was used to determine the homogeneity of the synthesized compounds.

Determination of Overlap Between Subcellular Fractions

$\underline{L D H}$. The extent of overlap between the $S_{3}$ and $P_{3}$ samples was determined by measuring lactate dehydrogenase (LDH) activity in the $P_{2}$ (synaptosomal), $S_{3}$ and $P_{3}$ fractions using a modification of the method of Barker et al. (1972). This enzyme exists in a soluble form (i.e., nonmembrane-bound) and thus any activity observed in the $P_{3}$ sample represents cytoplasmic contamination.

Brain minces were incubated and subcellular fractions prepared as previously described. An aliquot of the hypoosmotically ruptured $P_{2}$ fraction was removed prior to ultracentrifugation and separation of the $S_{3}$ and $P_{3}$ fractions. The $P_{3}$ fraction was subsequently homogenized in a total of $1.0 \mathrm{ml}$ of water. Bovine serum albumen was added to the $\mathrm{P}_{2}$ aliquot and the $S_{3}$ fraction to stabilize the enzyme. The final protein concentrations were equal for the three 
fractions. Triton $x-100$ was added to each sample assayed to a final concentration of $1 \%(\mathrm{v} / \mathrm{v})$ and allowed to stand in ice for 3-4 hrs. An aliquot of each sample was added to a buf-

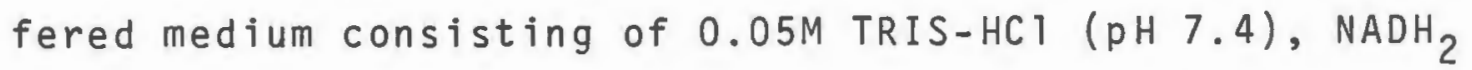
(87.6uM) and sodium pyruvate (346.0uM). The rate of oxidation of $\mathrm{NADH}_{2}$ was determined by measuring the change in absorbance at $340 \mathrm{~nm}$ over $3-4$ minutes at $25^{\circ} \mathrm{C}$ in a Gilford single beam spectrophotometer. Blanks consisted of sample, TRIS-HCl buffer and $\mathrm{NADH}_{2}$ and demonstrated little auto-oxidation during this time interval. The results indicated that $65 \%$ of the $P_{2}$ LDH activity was associated with the $S_{3}$ fraction and approximately $35 \%$ with the $P_{3}$ fraction.

Distribution of Choline-0-Acetyltransferase

The extent of overlap between the $S_{3}$ and $P_{3}$ fractions was further demonstrated by determining the amount of ChAT activity present in each fraction. Subcellular fractions were prepared as described previously. The $P_{3}$ pellet was washed $(2 \times 1 \mathrm{ml})$ with a $100 \mathrm{mM}$ sodium phosphate buffer ( $\mathrm{pH}$ 7.4) to remove the ChAT that became membrane-bound subsequent to the hypo-osmotic rupture of the $P_{2}$ fraction. ChAT activity was determined by the method of McCaman and Hunt (1965) as modified by Fonnum (1969) and described by Spyker et al. (1972). The majority of enzyme activity ( $84 \%$ ) was found in the $S_{3}$ and combined washes, whereas, $15.6 \%$ of the recovered $P_{2}$ activity was associated with the $P_{3}$ pellet. 


\section{MATERI ALS}

Choline chloride $1,2{ }^{14} \mathrm{C}$ - spec. act. $6.34 \mathrm{mCi} / \mathrm{mmol}$, acetylcholine iodide (acetyl-1- ${ }^{14} \mathrm{C}$ ) - spec. act. $1.2 \mathrm{mCi} / \mathrm{mmol}$, ATP ${ }^{32} \mathrm{P}$ spec. act. $17-35 \mathrm{Ci} / \mathrm{mmol}$, toluene standard $14 \mathrm{C}$, acetyl Co $A\left(\right.$ acetyl-1- ${ }^{14} \mathrm{C}$ ) - spec. act. adjusted to $2 \mathrm{mCi} / \mathrm{mmol}$, methyl ${ }^{14} \mathrm{C}$ spec. act. 20.0 and $49.0 \mathrm{mCi} / \mathrm{mmol}$, were obtained from New England Nuclear Corporation, (Boston, MA). Unlabelled methyl iodide and 3-dimethylamino-l-propanol and 3-heptanone were purchased from Aldrich Chemicals (Milwaukee, WI). Acetic anhydride was obtained from Eastman Kodak Co. (Rochester, NY). Acetyl-CoA was obtained from Calbiochem (San Diego, CA). Choline kinase (E.C.2.7.1.32), ACHE (E.C. 3.1.1.7) and paraoxon were obtained from Sigma Corporation (St. Louis, MO). Sodium tetraphenylboron was obtained from Fisher (Medford, MA). 


\section{RESULTS}

\section{Alteration of Nerve Ending Choline and ACh Levels in Mouse} Forebrain Minces.

Brain minces were incubated for 30 minutes in a krebs or a lithium high $K^{+}$(L.K.) Krebs medium and the ACh and choline content of the cytoplasmic $\left(S_{3}\right)$ and crude vesicular $\left(P_{3}\right)$ fractions determined. The results shown in Table 1 indicate that although $S_{3}$ ACh content didnot differ between treatments, lithium incubation did result in a $70 \%$ reduction of $\mathrm{P}_{3} \mathrm{ACh}$ levels, when compared to minces incubated in Krebs media. Conversely, $S_{3}$ choline levels were significantly reduced $(29 \%)$ as a result of $L$. K. Krebs treatment, while the amount of choline in the $P_{3}$ fraction was only slightly $(11 \%)$ lowered, (Table 3 ).

The transport of extracellular choline into the presynaptic nerve terminal for ACh synthesis has been established as a sodium dependent process (Dowda11 and Simon, 1973: Kuhar et al., 1973; Simon et al., 1976). Thus the observed lowering of $\mathrm{P}_{3} \mathrm{ACh}$ levels of minces incubated in the lithium containing solutions with either $10 \mathrm{~W} \mathrm{Na}+\left(\mathrm{NaHCO}_{3}, 28 \mathrm{mM}\right)$ or no added $\mathrm{Na}+\left(\mathrm{KHCO}_{3}\right.$ substituted for $\left.\mathrm{NaHCO}_{3}, 28 \mathrm{mM}\right)$, may reflect the lack of an adequate sodium ion concentration rather than the presence of lithium. To test this possibility, one set of forebrain minces were incubated in a normal krebs medium 
(total $\mathrm{Nat}=145 \mathrm{mM}$ ), while contralateral minces were similarly incubated in a low $\mathrm{Na}+$ Krebs medium ( $L \mathrm{C} C \mathrm{Cl}$ replaced by equiosmolar sucrose, total $\mathrm{Na}+=28 \mathrm{mM}$ ). Incubation of tissue in the low $\mathrm{Na}$ + Krebs solution resulted in a $50 \%$ reduction of $\mathrm{P}_{3} \mathrm{ACh}$ levels relative to minces incubated in the normal Krebs medium. However, unlike that observed after L. K. Krebs treatment, the levels of $S_{3} A C h$ were also reduced by nearly $30 \%$ relative to control tissue. The effect of lowered $\mathrm{Nat}$ on $\mathrm{S}_{3}$ and $\mathrm{P}_{3}$ choline levels was not determined in this study.

Ability of Extracellular Choline to Refill A Vesicle-Bound Transmitter Pool With Newly Synthesized ACh.

Incubation of forebrain minces in a Krebs solution containing lithium results in the depletion of $P_{3}$, but not $S_{3}$, ACh (Table 1). To determine whether a depleted vesicular transmitter pool can be refilled with newly synthesized $A C h$ formed from extracellular choline, minces, preincubated in Krebs or L. K. Krebs were incubated an additional 30 minutes in Krebs containing $\left[{ }^{14} \mathrm{C}\right]$ choline $(0.1 \mathrm{mM})$. The results shown in Table 4 indicate that the total $P_{3} A C h$ content of minces pretreated in Krebs or L. K. Krebs did not differ significantly. However, more newly synthesized $\left[{ }^{14} C\right] A C h$ was measured in the repleted than in the nondepleted $P_{3}$ fractions, (5.1 nmoles/gm and 2.6 nmoles/gm, respectively) resulting in a ratio of $\left[{ }^{14} \mathrm{C}\right] A C h$ to total $A C h$ in the repleted $P_{3}$ fraction 
(0.63) that exceeded that achieved in the same fraction of Krebs preincubated minces (0.35), (Fig. 2). Preincubation of tissue in the lithium containing medium did not result in any greater amount of $\left[{ }^{14} \mathrm{C}\right] \mathrm{ACh}$ appearing in the $S_{3}$ fraction, when compared to the same fraction of nondepleted minces pretreated in Krebs media.

Additionally, when compared to the $\mathrm{P}_{3}$ fraction of Krebs preincubated minces, substantially more unacetylated $\left[{ }^{14} \mathrm{C}\right]$ choline was found associated with the repleted $P_{3}$ fraction of minces previously exposed to the Krebs solution containing lithium (Table 5). Conversely, similar amounts of $\left[{ }^{14} \mathrm{C}\right]$ choline were measured in the $S_{3}$ fraction of Krebs and $L$. K. Krebs preincubated minces.

Repletion of the P 3 Fraction with Newly Formed Acetylhomocholine Derived from the Extracellular Precursor-Homocholine

As previously stated, homocholine differs from the natural precursor choline in that it appears not to be a suitable substrate for solubilized (i.e., cytoplasmic) ChAT (Currier and Mautner, 1974; Barker and Mittag, 1975; Collier et al., 1977). Thus if a depleted $P_{3}$ fraction was refilled with newly synthesized acetylhomocholine ( $A H C$ ) formed from extracellular homocholine, an alternative site of synthesis would be proposed to exist which serves the purpose of vesicular refilling.

To examine this possibility, forebrain minces were preincubated in Krebs or L. K. Krebs and incubated an additional 
30 minutes in krebs containing $\left[{ }^{14} \mathrm{C}\right]$ homocholine $(0.1 \mathrm{mM})$. As seen in Table 4, the total amount of acetylated product ( $A C h$ and $A H C$ ) in the $P_{3}$ fraction of minces after Krebs or $L$. K. Krebs pretreatment, was similar $(9.3$ nmoles/gm and 7.3 nmoles/ gm, respectively). However, the ratio of newly synthesized $\left[{ }^{14} \mathrm{C}\right] \mathrm{AHC}$ to $\mathrm{ACh}$ in the $\mathrm{P}_{3}$ fraction of minces exposed to the lithium solution (7.26) exceeded that attained in the same fraction of minces pretreated in Krebs media (0.46) (Fig. 3). As with $\left[{ }^{14} \mathrm{C}\right]$ choline incubated minces described above, the repleted $P_{3}$ fraction contained greater amounts of $\left[{ }^{14} \mathrm{C}\right] \mathrm{AHC}$ $(4.7 \mathrm{nmoles} / \mathrm{gm})$ than the nondepleted $\mathrm{P}_{3}$ fraction of Krebs preincubated minces ( 2.1 nmoles/gm) (Table 4). Additional$1 y$, the ratio of $\left[{ }^{14} \mathrm{C}\right] \mathrm{AHC}$ to $A C h$ in the repleted $\mathrm{P}_{3}$ fraction (7.26) exceeded that attained in the $S_{3}$ fraction $(0.44)$ of the same minces.

A net accumulation of unacetylated $\frac{1}{4}^{14} \mathrm{C}$ ]homocholine occurred in the $P_{3}$ fraction of $L$. K. Krebs preincubated minces $(7.2 \mathrm{nmoles} / \mathrm{gm})$ relative to the nondepleted $P_{3}$ fractions $(4.1 \mathrm{nmoles} / \mathrm{gm})$. Lithium high $\mathrm{K}^{+}$Krebs preincubation did not augment the amount of unacetylated precursor existing in the $S_{3}$ fraction when compared to Krebs preincubated minces. However, a greater amount of newly synthesized $\left[{ }^{14} \mathrm{C}\right] \mathrm{AHC}$ existed in the $S_{3}$ fraction of depleted minces $(5.3$ nmoles/gm) when compared to those minces pretreated in Krebs media ( 3.4 nmoles/gm), thus resulting in a higher ratia of $\left[{ }^{14} \mathrm{C}\right] \mathrm{AHC}$ to $\mathrm{ACh}$ in this fraction of L. K. Krebs $(0.44)$ relative to krebs $(0.26)$ preincubated minces (Fig. 3 ). It 
should be noted that the total amount of acetylated product ( $A C h$ and $A H C$ ) did not differ between pretreatments (Table 4 ). Similar results were obtained when mouse brain hippocampal minces were exposed to $\left[\left[^{14} \mathrm{C}\right]\right.$ homocholine $(0.1 \mathrm{mM})$. As seen in Table 8 , the total amount of acetylated product in the $P_{3}$ fraction did not differ between Krebs $(4.25 \mathrm{nmole} / \mathrm{gm})$ and L. K. Krebs $(4.0 \mathrm{nmoles} / \mathrm{gm})$ pretreated minces. However, the amount of newly synthesized $\left[{ }^{14} \mathrm{C}\right] \mathrm{AHC}$ in the repleted $\mathrm{P}_{3}$ fraction (2.03 nmoles/gm) was greater than that measured in the $P_{3}$ fraction of Krebs preincubated minces $(0.61 \mathrm{nmoles} / \mathrm{gm})$. Thus the ratio of labelled AHc to $A C h$ in the $P_{3}$ fraction of L. K. Krebs preincubated minces exceed that in the same fraction after Krebs pretreatment $(1.05$ and 0.29 , respectively; $n=2)$. Additionally, the ratio of labelled AHC to ACh in the repleted $P_{3}$ fraction (1.05) exceeded that of the $S_{3}$ fraction $(0.16)$ of minces preincubated in L. K. Krebs.

Greater amounts of unacetylated $\left[{ }^{14} \mathrm{C}\right]$ homocholine existed in the repleted $P_{3}$ fraction $(3.0 \mathrm{nmoles} / \mathrm{gm})$ relative to the nondepleted $P_{3}$ compartment $(1.6 \mathrm{nmoles} / \mathrm{gm})$; a result similar to that observed in the repleted $P_{3}$ fraction of forebrain minces. Additionally, more $\left[{ }^{14} \mathrm{C}\right]$ homocholine was transported into the $S_{3}$ fraction of repleted hippocampal minces with greater amounts of $\left[{ }^{14} C\right] A H c$ being synthesized when compared to the same fraction of Krebs preincubated minces. As seen in Table 8 , the ratio of $\left[{ }^{14} \mathrm{C}\right] \mathrm{AHC}$ to $\mathrm{ACh}$ in the $\mathrm{S}_{3}$ fraction of repleted minces $(0.16)$ exceeded that attained 
in the same fraction of Krebs preincubated minces $(0.04 ; n=2)$. Accumulation of the Extrace 11 ular Products $-\left[{ }^{14} \mathrm{C}\right] \mathrm{ACh}$ and $\left[{ }^{14} \mathrm{C}\right] \mathrm{AHC}$ by the $\mathrm{S}_{3}$ and $\mathrm{P}_{3}$ Compartments

The results reported above indicate that the lithium induced depletion of $\mathrm{P}_{3}$ ACh results in the refiling of this fraction with newly synthesized product formed from extracellular precursors. It was of interest to ascertain the disposition of the depleted $P_{3}$ fraction towards the utilization of the extracellular preformed products - ACh or AHC. Minces were preincubated as before and subsequently incubated an additional 30 minutes in Krebs containing $0.1 \mathrm{mM}\left[{ }^{14} \mathrm{C}\right] \mathrm{ACh}$ or $\left[{ }^{14} \mathrm{C}\right] \mathrm{AHC}$ and subcellular fractions prepared as described previous iy.

Accumulation of Extracellular $\left[{ }^{14} \mathrm{C}\right] \mathrm{ACh}$

The results shown in Table 6 indicate that after a 30 minute incubation in krebs with $\left[{ }^{14} \mathrm{C}\right] \mathrm{ACh}$, the total $\mathrm{ACh}$ content did not differ significantly between Krebs (15.8 nmoles/ $\mathrm{gm})$ and L.K. Krebs $(12.6 \mathrm{nmoles} / \mathrm{gm})$, pretreatments in the $\mathrm{P}_{3}$ fraction. However, unlike that observed with $\left[{ }^{14} \mathrm{C}\right]$ choline, the depleted $P_{3}$ fraction of $L$. K. Krebs exposed minces did not contain a greater amount of $\left[{ }^{14} \mathrm{C}\right] \mathrm{ACh}(1.8 \mathrm{nmoles} / \mathrm{gm})$ when compared to the same fraction of contralateral minces (1.5 nmoles/gm) preincubated in Krebs media. The ratio of labelled to total ACh therefore, in the $\mathrm{P}_{3}$ fraction of repleted tissues $(0.20)$ did not differ significantly from the 
$P_{3}$ fraction of nondepleted minces $(0.14)$ (Fig. 4). The results in Figure 4 further indicate that the ratio of $\left[{ }^{14} \mathrm{C}\right] \mathrm{ACh}$ to total $A C h$ in the $P_{3}$ fraction after either pretreatment did not exceed the ratios attained in the associated $S_{3}$ fractions. Accumulation of Extracellular $\left[{ }^{14} \mathrm{C}\right] \mathrm{AHC}$

Table 6 indicates that similar amounts of acetylated product ( $A C h$ and $A H C$ ) existed in the $P_{3}$ fractions between pretreatments. Additionally, as was observed when forebrain tissues were incubated with preformed $A C h$, the repleted $P_{3}$ fraction did not accumulate significantly more $\left[{ }^{14} \mathrm{C}\right]$ AHC when compared to the $P_{3}$ fraction of nondepleted minces. Thus, the ratio of $\left[{ }^{14} C\right] A H C$ to $A C h$, in the $P_{3}$ fraction did not differ significantly between pretreatments $(0.09$ and 0.09$)$ (Fig. 5). Similarly, the ratio of $\left[{ }^{14} \mathrm{C}\right] \mathrm{AHC}$ to $\mathrm{ACh}$ in the $\mathrm{P}_{3}$ fraction $(0.09)$ did not exceed that attained in the $S_{3}$ fraction (0.22) after L. K. Krebs preincubation. Somewhat different results were obtained when mouse brain hippocampal minces were incubated in media containing $\left[{ }^{14} \mathrm{C}\right] \mathrm{AHC}(0.1 \mathrm{mM})$. Although the total amount of acetylated product did not differ significantly from the $\mathrm{P}_{3}$ fraction of nondepleted minces (2.71 nmoles/gm), a greater amount of $\left[{ }^{14} \mathrm{C}\right]$ AHc existed in the $P_{3}$ fraction of $L$. K. Kreb pretreated minces $(0.65 \mathrm{nmoles} / \mathrm{gm})$ than in the $\mathrm{P}_{3}$ fraction after Krebs pretreatment $(0.26$ nmoles/ gm) (Table 8$)$. The resulting ratio of $\left[{ }^{14} \mathrm{C}\right] \mathrm{AHC}$ to $\mathrm{ACh}$ in the repleted $P_{3}$ fraction $(0.17)$ exceeded that measured in 
the same fraction of Krebs preincubated minces (0.11). However, it should be noted that the amount of preformed labelled product taken up into the $P_{3}$ fraction of $L$. $K$. Krebs preincubated minces was insufficient to refill the depleted transmitter pool.

Lithium pretreatment did not result in significantly greater amounts of $\left[{ }^{14} \mathrm{C}\right] \mathrm{AHC}$ existing in the $S_{3}$ fraction relative to Krebs preincubated minces. Similarly, the ratio of $\left[{ }^{14} \mathrm{C}\right] \mathrm{AHC}$ to $\mathrm{ACh}$ in the $S_{3}$ fraction of $L$. K. Krebs preincubated minces did not differ significantly from those preincubated in Krebs media $(0.16$ and 0.12 , respectively, Table 8).

Depletion of $P_{3} A C h$ and Its Effect Upon the Transport of Extracellular Precursors and Products

Dowdall and Whittaker (1975) and Jenden et al. (1976) have reported that the pre-existing nerve terminal levels of ACh regulate the transport of extracellular choline into the nerve ending. Table 7 summarizes the effect the lithiuminduced depletion of $\mathrm{P}_{3} \mathrm{ACh}$ has upon the transport of the extracellular precursors $\left[{ }^{14} \mathrm{C}\right]$ choline and $\left[{ }^{14} \mathrm{C}\right]$ homocholine and the preformed products $\left[{ }^{14} \mathrm{C}\right] \mathrm{ACh}$ and $\left[{ }^{14} \mathrm{C}\right] \mathrm{AHC}$ into forebrain or hippocampal minces.

The reduction of $P_{3} A C h$ in forebrain minces augmented the transport of the extracellular precursors $\left[{ }^{14} \mathrm{C}\right]$ choline $(84 \%)$ and $\left[{ }^{14} \mathrm{C}\right]$ homocholine $(76 \%)$ into the repleted $P_{3}$ 
fraction relative to the nondepleted krebs preincubated tissue. Transport of either precursor into the $S_{3}$ fraction of forebrain minces was not altered by exposure to the lithium containing media; although greater amounts of newly synthesized $\left[{ }^{14} C\right.$ ] AHC existed in the $S_{3}$ fraction of $L$. K. Krebs, relative to krebs, preincubated minces. Similarly, lithium pretreatment increased $(124 \%)$ the amount of $\left[{ }^{14} \mathrm{C}\right]$ homocholine transported into the repleted relative to the nondepleted $P_{3}$ fraction of hippocampal minces. However, L. K. Krebs pretreatment also increased $(57 \%)$ the amount of $\left[{ }^{14} \mathrm{C}\right]$ homocholine transported into the $S_{3}$ fraction when compared to Krebs nondepleted minces.

Conversely, in forebrain tissue, depletion of $\mathrm{P}_{3} \mathrm{ACh}$ did not result in a greater transport of extracellular preformed $\left[{ }^{14} \mathrm{C}\right] \mathrm{ACh}$ or $\left[{ }^{14} \mathrm{C}\right] \mathrm{AHC}$ into either the $\mathrm{S}_{3}$ or $\mathrm{P}_{3}$ fractions of L. K. Krebs preincubated minces relative to those minces preincubated in Krebs media. Similarly, in mouse hippocampal minces, L. K. Krebs pretreatment did not result in any greater accumulation of extracellular ${ }^{14} \mathrm{C}$ AHC into the $S_{3}$ fraction, when compared to the amount present in the $S_{3}$ fraction of nondepleted minces. However, the lithium induced depletion of $\mathrm{P}_{3}$ ACh did result in significantly $(150 \%)$ greater accumulation of extracellular ${ }^{14} C$ AHC into the repleted fraction, although in amounts insufficient to replace the lost transmitter. 


\section{DISCUSSION}

There is general agreement that $A C h$ is distributed bimodally between the cytoplasm and vesicles within the nerve terminals of cholinergic neurons (DeRobertis et al., 1963; Whittaker et al., 1964). However, the extent of biochemical interdependence, as well as the functional significance, of each compartment is presently unknown. The purpose of this investigation was to determine whether vesicles, depleted of $A C h$, could be refilled with newly synthesized transmitter (or false transmitter) independently of the cytoplasm. Specifically, it was of interest to ascertain whether vesicular $A C h$ is ultimately derived from a pool of $A C h$ synthesized within the cytoplasm.

The results presented in Table 1 , show that a krebs medium containing 1 ithium and elevated $(32.7 \mathrm{mM}) \mathrm{K}^{+}$selectively depletes the level of $A C h$ in a crude vesicular $\left(P_{3}\right)$ fraction without altering cytoplasmic $\left(S_{3}\right) A C h$ levels in mouse forebrain minces. Furthermore, lowering the $\mathrm{K}^{+}$concentration ( $4.7 \mathrm{mM})$ in the 1 ithium Krebs medium did not enhance nor antagonize this differential effect upon nerve terminal stores of transmitter, indicating that the addition of $\mathrm{K}^{+}$ does not alter the central metabolism of ACh.

The presynaptic transport of extracellular choline for ACh formation, is sodium dependent (Simon et al., 1975; Simon 
and Kuhar, 1976), and thus, the reduction of $P_{3} A C h$ levels may, in part, be attributable to a lack of an adequate sodium ion concentration in the incubation medium. Treatment of forebrain minces in a low (28mM) sodium ( 1 ithium free) krebs solution results in a $50 \%$ reduction of $P_{3} A C h$ levels, as compared to the $P_{3}$ fraction of minces incubated in a normal $\left(145 \mathrm{mM} \mathrm{Na}^{+}\right)$Krebs medium. However, in addition, a $30 \%$ reduction of $\mathrm{S}_{3} \mathrm{ACh}$ content was observed after low sodium Krebs incubation; a result different from that observed when minces are incubated in the lithium krebs media. Thus, qualitative, as well as quantitative, differences exist, pertaining to $A C h$ metabolism, when minces are incubated in the two modified Krebs media.

The lithium-induced reduction of $P_{3} A C h$ content may be explained in the following way. According to Keynes and Swan (1959) lithium, like elevated $\mathrm{K}^{+}$, depolarizes nerve terminals. Incubation of brain minces in lithium Krebs, lithium high $\mathrm{K}^{+}$Krebs or high $\mathrm{K}^{+}$Krebs will release similar amounts of endogenous $A C h$ from the $P_{3}$ fraction, thereby lowering its content. Exposure of minces to high $\mathrm{K}^{+}$Krebs augments the $\mathrm{Ca}^{2+}$-dependent release of $\mathrm{P}_{3} \mathrm{ACh}$ while allowing extraceliular choline to be transported into the presynaptic nerve terminal, acetylated and released. A net synthesis of ACh thus occurs during tissue incubation in high $\mathrm{K}^{+}$ Krebs media (Salehmoghaddam and Collier, 1976). Lithium, however, in addition to depolarizing nerve terminals, also blocks choline transport presynaptically (Simon and Kuhar, 
1976) thereby limiting the availability of precursor and thus preventing the repletion of $P_{3}$ stores of transmitter with newly synthesized $A C h$. It is important to note that lithium does support ChAT activity (Potter et al., 1968). The selective depletion of $P_{3} A C h$ levels may reflect a more immediate requirement by this compartment, relative to the $S_{3}$ fraction, for extracellular choline.

Minces, preincubated in the L. K. Krebs medium with subsequent exposure to Krebs containing $\left[{ }^{14} \mathrm{C}\right]$ choline, demonstrated a higher ratio of labelled to total $\mathrm{ACh}$ in the repleted $P_{3}$ fraction (0.63) relative to that attained by the $S_{3}(0.33)$ fraction. Similarly, incubation of depleted forebrain minces in the presence of the labelled choline analog $\left[{ }^{14} \mathrm{C}\right]$ homocholine, produced a greater ratio of labelled AHC to $A C h$ in the repleted $P_{3}$ fraction $(7.26)$ relative to the $S_{3}$ fraction (0.44). Thus it appears that depleted vesicular stores of transmitter are refilled with newly synthesized product formed in close association with the $P_{3}$ fraction rather than through mobilization of preformed cytoplasmic ACh. Qualitatively analogous results were obtained when hippocampal minces were incubated in the presence of $\left[{ }^{14} \mathrm{C}\right]$ homocholine. The lithium-induced depletion of $\mathrm{P}_{3} \mathrm{ACh}$ resulted in a higher ratio of labelled AHc (1.50) to ACh appearing in this fraction when compared to the $S_{3}$ fraction $(0.33)$.

Several investigators have reported that homocholine is not readily acetylated by cytoplasmic ChAT (Currier and 
Mautner, 1974; Barker and MiHog, 1975; Collier et al., 1977). Thus it was unexpected that nearly equivalent amounts of newly synthesized $\left[{ }^{14} \mathrm{C}\right]$ AHc were measured in the $P_{3}(4.7 \mathrm{~nm}$ loles/ $\mathrm{gm})$ and the $S_{3}(5.3 \mathrm{nmoles} / \mathrm{gm})$ fractions of lithium pretreated minces. However, it is possible that the $\left[{ }^{14} C\right]$ AHC found associated with the $S_{3}$ fraction may have originated from that synthesized by a membrane-bound ChAT (located on or near the vesicular and/or neuronal membranes), which is released from the enzymes synthetic site into the cytoplasm.

Depletion of forebrain $\mathrm{P}_{3}$ ACh content augments the transport of extracelluiar $\left[{ }^{14} \mathrm{C}\right]$ choline $(84 \%)$ and $\left[{ }^{14} \mathrm{C}\right]$ homocholine $(76 \%)$ into this compartment but not into the $S_{3}$ fraction suggesting that repletion of $P_{3}$ stores of ACh occurs independently of the $S_{3}$ fraction possibly through direct accumulation of extracellular precursor. Hippocampal minces depleted of $P_{3} A C h$ also demonstrated an enhanced uptake of $\left[{ }^{14} \mathrm{C}\right]$ homocholine $(126 \%)$ relative to the nondepleted $P_{3}$ fraction. However, $58 \%$ more $\left[{ }^{14} \mathrm{C}\right]$ homocholine was transported into the $\mathrm{S}_{3}$ fraction of L. K. Krebs preincubated minces relative to the same fraction of krebs pretreated minces. The reason for the difference between forebrain and hippocampal minces regarding the transport of labelled homocholine into the $S_{3}$ fraction is not readily explainable. However, 2.5 times more $\left[{ }^{14} \mathrm{C}\right]$ AHC was found in the $S_{3}$ fraction of $L$. K. Krebs pretreated hippocampal minces relative to the $S_{3}$ fraction of Krebs preincubated tissue. 
Further evidence that the depleted $\mathrm{P}_{3}$ fraction is preferentially repleted with newly synthesized product formed from extracellular precursor rather than preformed $\mathrm{S}_{3} \mathrm{ACh}$, is derived from the observation that the total amount of acetylated product in the repleted $P_{3}$ fraction of forebrain minces incubated with $\frac{3}{4}{ }^{14} \mathrm{C}$ ]homocholine $\left(4.7\right.$ nmoles $\left[{ }^{14} \mathrm{C}\right] \mathrm{AHC} /$ gm plus 2.6 nmoles $A C h / g m)$ exceeded the amount of product in the lithium depleted $P_{3}$ fraction (2.5 nmoles $\left.A C h / g m\right)$ by the amount of newly formed $\left[{ }^{14} \mathrm{C}\right] \mathrm{AHC}$.

Forebrain minces, depleted of $\mathrm{P}_{3} \mathrm{ACh}$ and subsequently incubated in Krebs containing $\left.\frac{3}{4}{ }^{14} \mathrm{C}\right] \mathrm{ACh}$, demonstrated ratio of $\left[{ }^{14} \mathrm{C}\right] \mathrm{ACh}$ to total $\mathrm{ACh}$ in the repleted $\mathrm{P}_{3}$ fraction that did not exceed that attained in the $S_{3}$ fraction 10.20 and 0.14 , respectively). Similarly, incubation of lithium pretreated forebrain minces in Krebs containing $\left[{ }^{14} \mathrm{C}\right] \mathrm{AHC}$ resulted in a ratio of $\left[{ }^{14} \mathrm{C}\right] \mathrm{AHC}$ to $A C h$ in the repleted $P_{3}$ fraction (0.09) that did not exceed the ratio attained in the $S_{3}$ fraction $(0.09)$. It should be noted that 5.1 nmoles $\left[{ }^{14} \mathrm{C}\right] \mathrm{ACh} / \mathrm{gm}$ tissue was measured in the repleted $\mathrm{P}_{3}$ fraction after incubation with $\left[{ }^{14} \mathrm{C}\right]$ choline but only 1.7 nmoles $\left[{ }^{14} \mathrm{C}\right] \mathrm{ACh} / \mathrm{gm}$ tissue was measured in the repleted $\mathrm{P}_{3}$ fraction when minces were incubated with the preformed product. Similarly 4.7 nmoles $\left[{ }^{14} \mathrm{C}\right]$ AHc/gm tissue, formed from extracellular $\left[{ }^{14} C\right]$ homocholine, was found in the repleted $P_{3}$ fraction whereas only 1.2 nmoles of labelied product/gm tissue was associated with this fraction after exposure to preformed $\left[{ }^{14} \mathrm{C}\right] \mathrm{AHC}$. Thus newly synthesized and not preformed product can replete a depleted $P_{3}$ fraction. 
When L. K. Krebs pretreated hippocampal minces were postincubated in krebs containing $\left[{ }^{14} \mathrm{C}\right] \mathrm{AHC}$, similar ratios of $\left[{ }^{14} \mathrm{C}\right] \mathrm{AHC}$ to $\mathrm{ACh}$ were attained in the $\mathrm{S}_{3}$ and $\mathrm{P}_{3}$ fractions $(0.16$ and 0.17 , respectively). Furthermore, the total amount of preformed $\left.E^{14} \mathrm{C}\right] \mathrm{AHC}$ found in the repleted $\mathrm{P}_{3}$ fraction $[0.65$ nmoles/gm) was substantially less than the amount present in this fraction when hippocampal minces were incubated with labelled homocholine $\left(2.8\right.$ nmoles $\left.\left[{ }^{14} \mathrm{C}\right] \mathrm{AHc} / \mathrm{gm}\right)$. However a significantly greater amount of preformed $\left[{ }^{14} \mathrm{C}\right]$ AHc was accumulated by the repleted $P_{3}$ fraction $(0.65$ mmoles/gm) when compared to the nondepleted $P_{3}$ fraction of Krebs preincubated minces $(0.26 \mathrm{nmoles} / \mathrm{gm})$. It appears from these results that a $P_{3}$ fraction depleted of $A C h$ may accumulate preformed extracellular product directly although in amounts insufficient to replete the transmitter stores.

Collier et al. (1977), reported that preganglionic stimulation of the cat superior cervical ganglion resulted in increased tissue amounts of both unacetylated labelled homocholine and newly formed labelled AHc. The results of this study support this finding. In both forebrain and hippocampal minces, depletion of $P_{3} A C h$ resulted in substantially greater amounts of unacetylated $\left[{ }^{14} \mathrm{C}\right]$ choiline or $\left[{ }^{14} \mathrm{C}\right]$ homocholine appearing in the repleted $P_{3}$ fraction. This result may indicate that acetylation, and not substrate availability, is rate limiting in the repletion of transmitter stores. A similar interpretation was given by Collier et al. (1977). 
However, it is possible that the unacetylated precursor is sequestered in a location not accessible to ChAT. Kadota et al. (1974), reported that the monodisperse vesicle fraction of the nerve terminal contain primarily choline and little acetylated product. Until it is determined that the unacetylated precursors are not entering such a pool and are in fact associated with the synaptic vesicles of the $\mathrm{P}_{4}$ fraction, it can not be concluded that acetylation is rate limiting.

The results of this study indicate that the replacement of lost transmitter from the $\mathrm{P}_{3}$ or crude vesicular fraction occurs preferentially through the direct uptake and acetylation of extracellular precursor, independently of the $S_{3}$ or cytoplasmic compartment. Also that accumulation of preformed extraceliular product is not a means of repletion of vesicular transmitter stores. 
TABLE 1

Differential Effect of L. K. Krebs Treatment on the Acetyl Choline Content of $\mathrm{S}_{3}$ and $\mathrm{P}_{3}$ Fractions

Treatment

Subcellular Fractions

$\mathrm{S}_{3}$ nmoles/gm wet wgt. $\mathrm{P}_{3}$

Krebs

$11.8+1.6$

(12)

$8.7 \pm 0.9$

Lithium

Krebs

$12.8 \pm 2.5$

$2.5 \pm 0.4 *(12)$

Mouse forebrains were incubated for 30 minutes in Krebs or L. K. Krebs. Values represent the Mean + S.E.M. *Results differ significantly from Krebs at $P<0 . \overline{0} 5$ (Analys is of variance: one way classification). 
TABLE 2

Differential Effect of Lithium Low $\mathrm{K}^{+}$Krebs Treatment on the Acetylcholine Content of $S_{3}$ and $P_{3}$ Fractions

$\mathrm{S}_{3} \quad$ nmoles/gm wet wgt. $\mathrm{P}_{3}$

Krebs

$10.8 \pm 1.4$

$7.2 \pm 1.4$

Lithium

Krebs

$$
9.5 \pm 1.6
$$

$2.3 \pm 0.5^{*}$

Mouse forebrain minces were incubated for 30 minutes in Krebs or a lithium low $\mathrm{K}^{+}$Krebs medium. Values represent the Mean + S.E.M. ( )=experimental animals. *Results differ significantly from Krebs at $P<0.05$. (Analys is of variance: one way classification). 
TABLE 3

Differential Effect of L. K. Krebs Treatment on the Choline Content of $\mathrm{S}_{3}$ and $\mathrm{P}_{3}$ Fractions

$\mathrm{S}_{3} \quad$ nmoles/gm wet wgt. $\quad \mathrm{P}_{3}$

Krebs

$$
85.6 \pm 11.5
$$$$
29.1 \pm 4.6(12)
$$

Lithium Krebs

$60.6 \pm 8.4 *(12)$

$$
25.8 \pm 4.0
$$

Mouse forebrain minces were incubated for 30 minutes in Krebs or L. K. Krebs. Values represent the Mean + S.E.M. for 12 animals. *Results differ significantly from krebs at $P<0.05$ (Analysis of Variance: one way classification). 
TABLE 4

Ability of a Depleted $P_{3}$ Fraction to be Refilled with Newly Synthesized ACh or AHC Independently of the $\mathrm{S}_{3}{ }^{3}$ Fraction

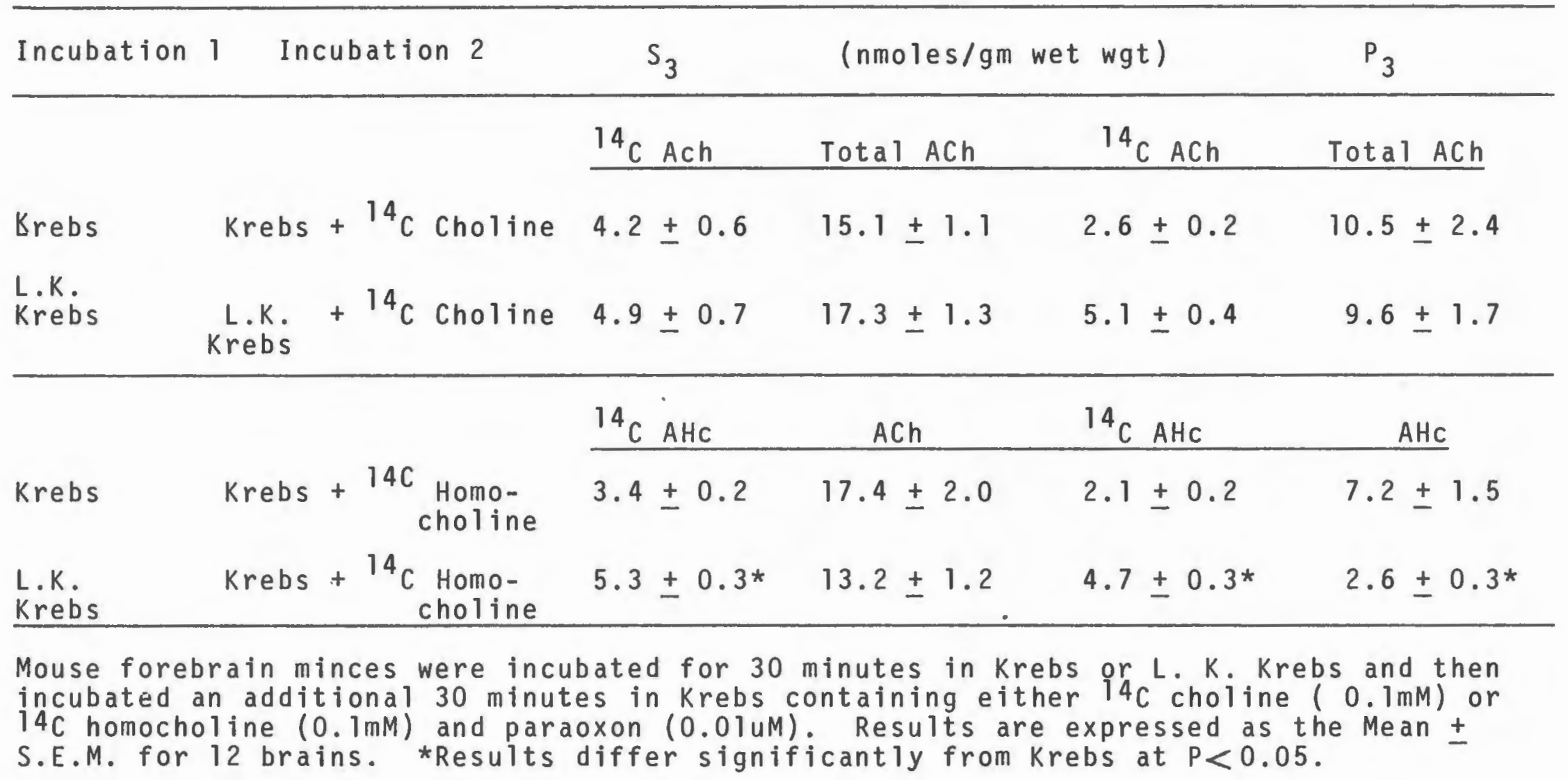


TABLE 5

Accumulation and Acetylation of Choline and Homocholine by Subcellular Fractions of Mouse Forebrain.

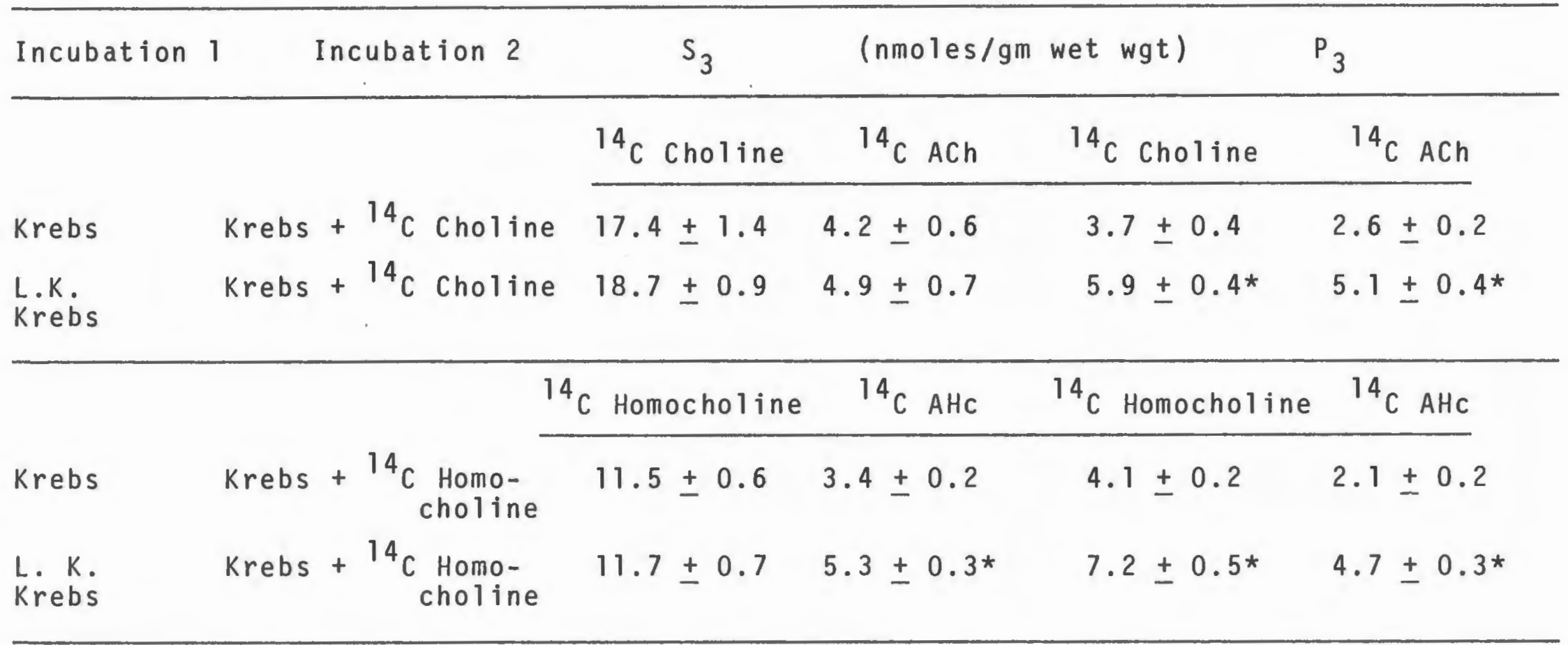

Forebrain minces were preincubated for 30 ming in either Krebs or L. K. Krebs followed by a $30 \mathrm{~min}$. incubation in Krebs containing ${ }^{4}{ }^{\mathrm{C}}$ choline or ${ }^{4} \mathrm{C}$ homocholine at $0.1 \mathrm{mM}$ concentrations and paraoxon (0.1uM). Results are expressed as the Mean $+S . E . M$. for 12 brains. *Results differ significantly from Krebs at $P<0.05$ (Analysis of variance one way classification). 
TABLE 6

Ability of a Depleted $P_{3}$ Fraction of Forebrain Minces to Accumulate the Preformed Acetylated Products $14 \mathrm{C} \mathrm{ACh}$ and $14 \mathrm{C} \mathrm{AHC}$.

\begin{tabular}{|c|c|c|c|c|c|c|}
\hline Incubation & 1 & Incubation 2 & $\mathrm{~S}_{3}$ & (nmoles/gm & wet wgt) & $P_{3}$ \\
\hline & & & ${ }^{14} \mathrm{CACh}$ & Total ACh & ${ }^{14} \mathrm{CACh}$ & Total ACh \\
\hline Krebs & Krebs & $+{ }^{14} \mathrm{CACh}$ & $11.9 \pm 0.5$ & $28.0 \pm 2.5$ & $1.5 \pm 0.2$ & $15.8 \pm 3.3$ \\
\hline \multirow[t]{2}{*}{ L.K. Krebs } & Krebs & $+{ }^{14} \mathrm{CACh}$ & $8.8 \pm 0.4$ & $23.8 \pm 2.4$ & $1.8 \pm 0.3$ & $12.6 \pm 1.7$ \\
\hline & & & ${ }^{14} \mathrm{CAHC}$ & $\mathrm{ACh}$ & ${ }^{14} \mathrm{CAHC}$ & $\mathrm{ACh}$ \\
\hline Krebs & Krebs & $+{ }^{14} \mathrm{CAHC}$ & $3.2 \pm 0.2$ & $22.9 \pm 3.4$ & $1.2 \pm 0.1$ & $15.5 \pm 2.6$ \\
\hline L.K. Krebs & Krebs & $+{ }^{14} \mathrm{CAHC}$ & $3.2 \pm 0.1$ & $16.1 \pm 1.9$ & $1.3 \pm 0.1$ & $15.4 \pm 2.1$ \\
\hline
\end{tabular}

Mouse forebrain minces were incubated initially in either a Krebs gr L. K. Krebs medium and subsequently incubated in krebs containing ${ }^{14} \mathrm{C} \mathrm{ACh}$ or $14 \mathrm{C}$ AHC and paraoxon $(0.14 M)$. Results are expressed as the Mean \pm S.E.M. for 12 animals. 
TABLE 7

Differential Effect of L. K. Krebs Pretreatment on the Movement of Extracellular Precursors - $14 \mathrm{C}$ Choline or $14 \mathrm{C}$ Homocholine and Acetylated Products $-{ }^{14} \mathrm{C} \mathrm{ACh}$ and ${ }^{14} \mathrm{C} \mathrm{AHc}$, into the $\mathrm{S}_{3}$ and $\mathrm{P}_{3}$ Fractions.

Incubation 1 Incubation 2

Forebrain

Krebs

Krebs $+{ }^{14} \mathrm{C}$ Choline

L.K. Krebs Krebs $+{ }^{14}$ C Choline

Krebs Krebs $+{ }^{14} \mathrm{C}$ Homochol.

L.K. Krebs Krebs $+{ }^{14}$ C Homochol.

Krebs Krebs $+{ }^{14} \mathrm{C} \mathrm{ACh}$

L.K. Krebs Krebs $+{ }^{14} \mathrm{C} \mathrm{ACh}$

Krebs $\quad$ Krebs $+{ }^{14} \mathrm{C} \mathrm{AHC}$

L.K. Krebs Krebs $+{ }^{14}$ C AHc

\section{Subcellular Fractions}

$$
\begin{array}{cc}
\stackrel{\mathrm{S}_{3}}{\mathrm{P}} & \underline{\mathrm{P}_{3}} \\
346.3 \pm 29.2 & 88.4 \pm 8.5 \\
377.0 \pm 17.2 & 163.0 \pm 8.3 * \\
87.5 \pm 2.8 & 34.6 \pm 1.3 \\
96.9 \pm 3.8 & 61.1 \pm 3.5 * \\
31.7 \pm 1.3 & 4.0 \pm 0.6 \\
23.2 \pm 1.1 * & 4.0 \pm 0.7 \\
33.6 \pm 1.8 & 12.6 \pm 1.1 \\
34.4 \pm 0.9 & 13.9 \pm 0.6
\end{array}
$$

Incubation 1 Incubation 2

Hippocampus

Krebs

$$
\text { Krebs }+{ }^{14} \mathrm{C} \text { Homochol. }
$$

$117.2(2)$
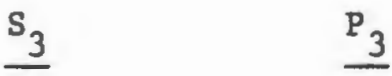

L.K. Krebs

Krebs $+{ }^{14} \mathrm{C}$ Homochol.

184.7 (2)

$15.6 \pm 2.3$

$19.3 \pm 1.8$
31.7

71.0

$$
3.2 \pm 0.4
$$$$
7.6 \pm 0.9 *
$$

Minces were preincubated in Krebs or L.K. Krebs, and subsequently incubated an additional $30 \mathrm{~min}$. in Krebs containing one of the following: $14 \mathrm{C}$ Choline (0.1mM; sp.act.13.65 dpm/pmol), $14 \mathrm{C}$ Homocholine (0.1mM, $5.1 \mathrm{dpm} / \mathrm{pmol}$ in forebrain exper. and $16.5 \mathrm{dpm} / \mathrm{pmol}$ in hippocampal studies), $14 \mathrm{C} \mathrm{ACh}(0.1 \mathrm{mM}, 2.65 \mathrm{dpm} / \mathrm{pmol}), 14 \mathrm{C} \mathrm{AHc}(0.1 \mathrm{mM}, 11.9 \mathrm{dpm} / \mathrm{pmol})$. Results expressed as Mean + S.E.M. *Differ significantly from Krebs at $\mathrm{P}<0.05$ (Anal. of Var.: One way classification). 
TABLE 8

Ability of a Depleted $P_{3}$ Fraction of Hippocampal Minces to be with Acetylhomocholine Formed from Extracellular Homocholine or Preformed Product

\section{Treatment 1 Treatment 2}

Subcellular Fractions

$\mathrm{S}_{3}$

$P_{3}$

\begin{tabular}{|c|c|c|c|c|c|c|c|c|c|c|c|}
\hline \multirow[b]{2}{*}{ Krebs } & \multirow[b]{2}{*}{ Krebs +} & \multirow[b]{2}{*}{$+{ }^{14} C$} & \multirow{2}{*}{\multicolumn{2}{|c|}{ Homocholine }} & & \multirow{2}{*}{$\frac{{ }^{14} \mathrm{C} A H C}{1.1}$} & \multirow{2}{*}{$\frac{A C h}{16.3}$} & \multirow{2}{*}{$\begin{array}{c}R \\
0.07\end{array}$} & \multicolumn{2}{|c|}{${ }^{14} \mathrm{CAHC} A C h$} & \multirow{2}{*}{$\frac{R}{0.14}$} \\
\hline & & & & & & & & & 0.06 & 4.2 & \\
\hline L.K. Krebs & Krebs + & $+{ }^{14} C$ & Homc & choline & & 2.9 & 9.2 & 0.33 & 2.1 & 1.7 & 1.50 \\
\hline & & & & ${ }^{14} \mathrm{C} \mathrm{AHC}$ & $\mathrm{ACh}$ & $\mathrm{R}$ & ${ }^{14} \mathrm{C}$ & $\mathrm{AHC}$ & $A C h$ & & $R$ \\
\hline Krebs & Krebs + & $+{ }^{14} C$ & $\mathrm{AHC}$ & $1.3 \pm 0.2$ & $11.4 \pm 2.5$ & $0.12 \pm 0.02$ & $0.3 \pm$ & .02 & $2.5 \pm 0.3$ & 0.1 & $1 \pm 0.01$ \\
\hline L.K. Krebs & Krebs + & $+{ }^{14} C$ & $\mathrm{AHC}$ & $1.6 \pm 0.2$ & $11.8 \pm 3.1$ & $0.16 \pm 0.04$ & $0.65 t$ & $+0.08 *$ & $* 4.0 \pm 0.7$ & 0.1 & $7 \pm 0.02 *$ \\
\hline
\end{tabular}

Mouse brain hippocampal minces were incubated initially in Krebs or L.K. Krebs and subsequently incubated in Krebs containing $0.1 \mathrm{mM}$ concentrations of labelled homocholine or labelled AHc. Results are expressed as Mean \pm S.E.M. for incubation with labelled AHc $(n=3)$. Incubation with labelled homocholine was performed twice and expressed as the Mean of 2 experiments. $R=$ ratio of 1 abelled AHC to ACh; all other values are as nmoles/gm wet wgt. *Results differ significantly at $P<0.05$. 
FIGURE I

SUBCELLULAR FRACTIONATION SCHEME OF BRAIN TISSUE

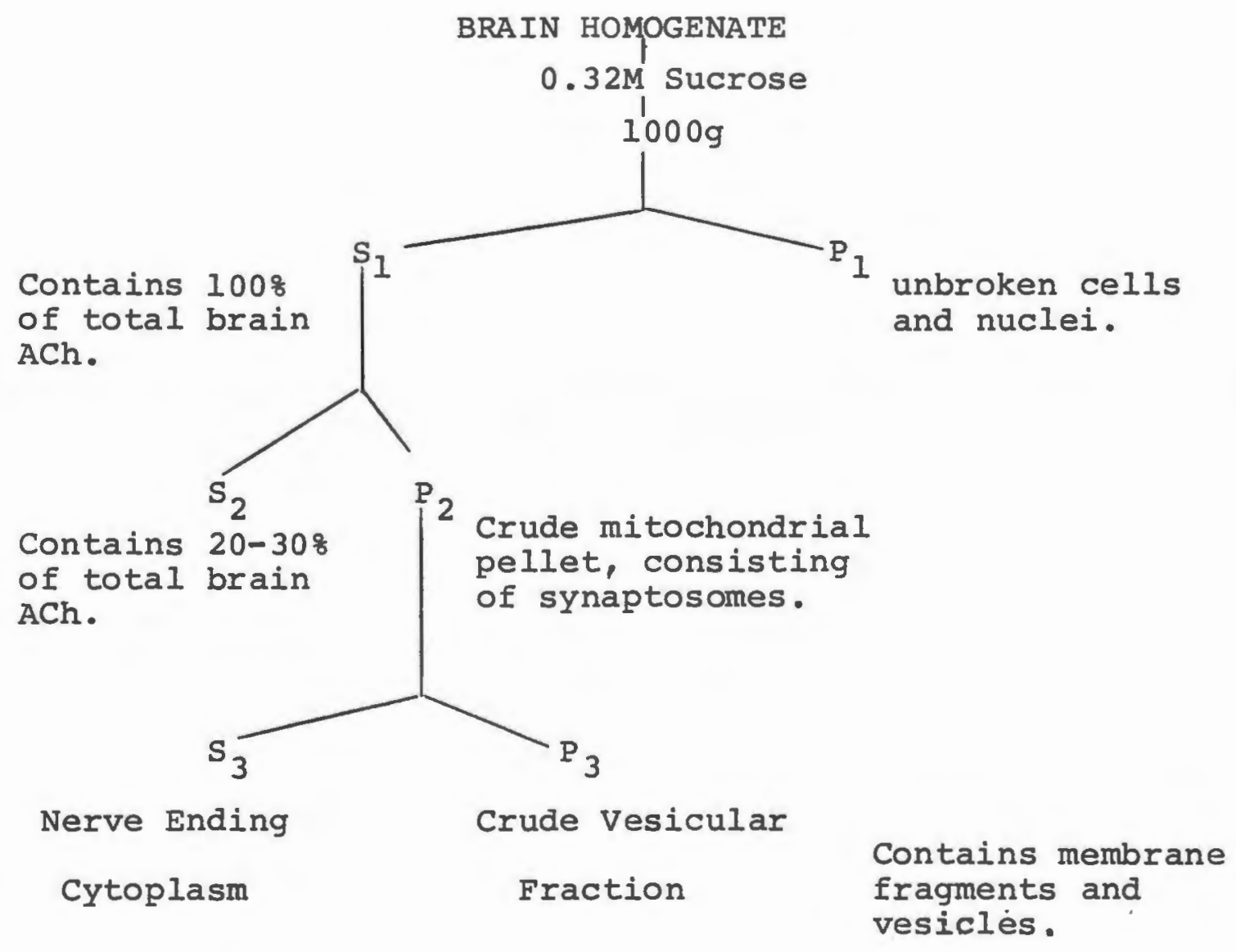


FIGURE II

INCUBATION IN N.K. WITH 100 UM( $\left.{ }^{14} \mathrm{C}\right)$ CHOLINE AFTER PREINCUBATION IN N.K. OR Li+K.

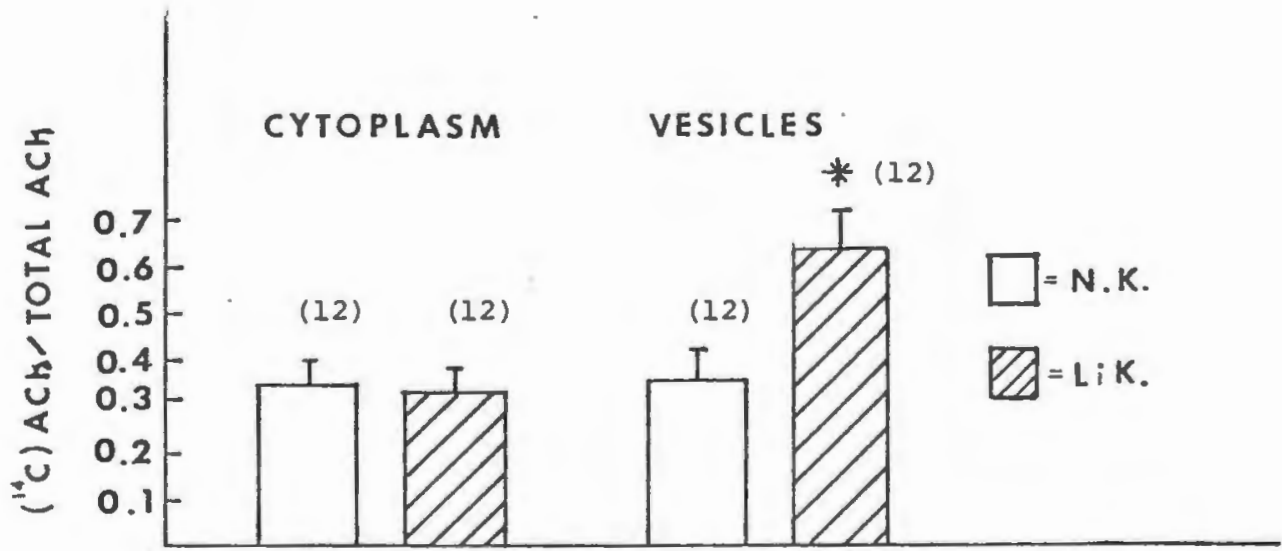

Values represent the mean \pm S.E, for ratio of label to total ACh in subceliular fractions. An asterisk indicates a significant difference, $P<0.05$ (znalysis of Variance: one way classification). ( $l=$ experimental animals used. 
FIGURE III

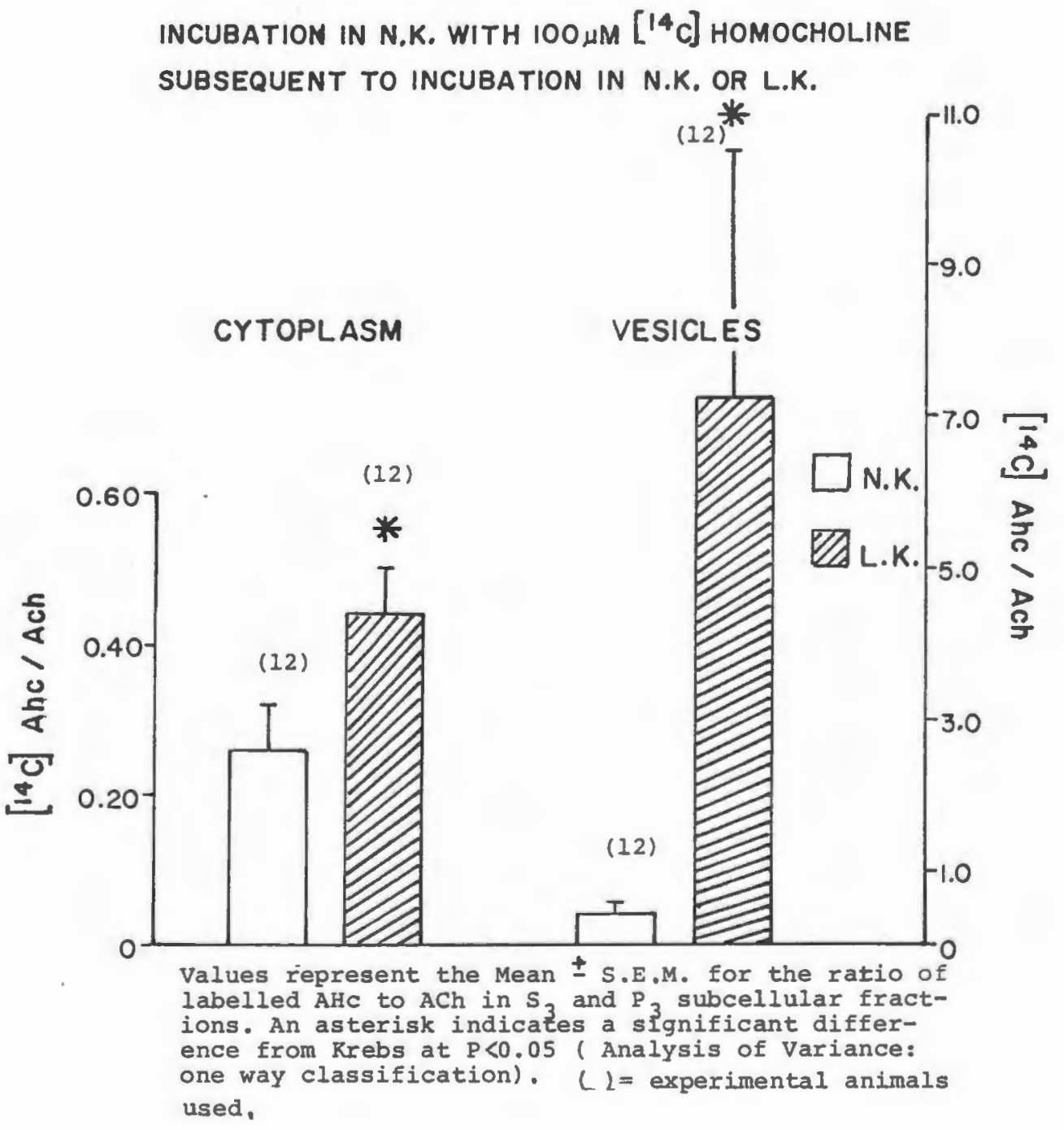


FIGURE IV

INCUBATION IN N.K.WITH 100 UM $\left({ }^{14} \mathrm{C}\right)$ ACh SUBSEQUENT TO INCUBATION IN N.K. OR LIK.

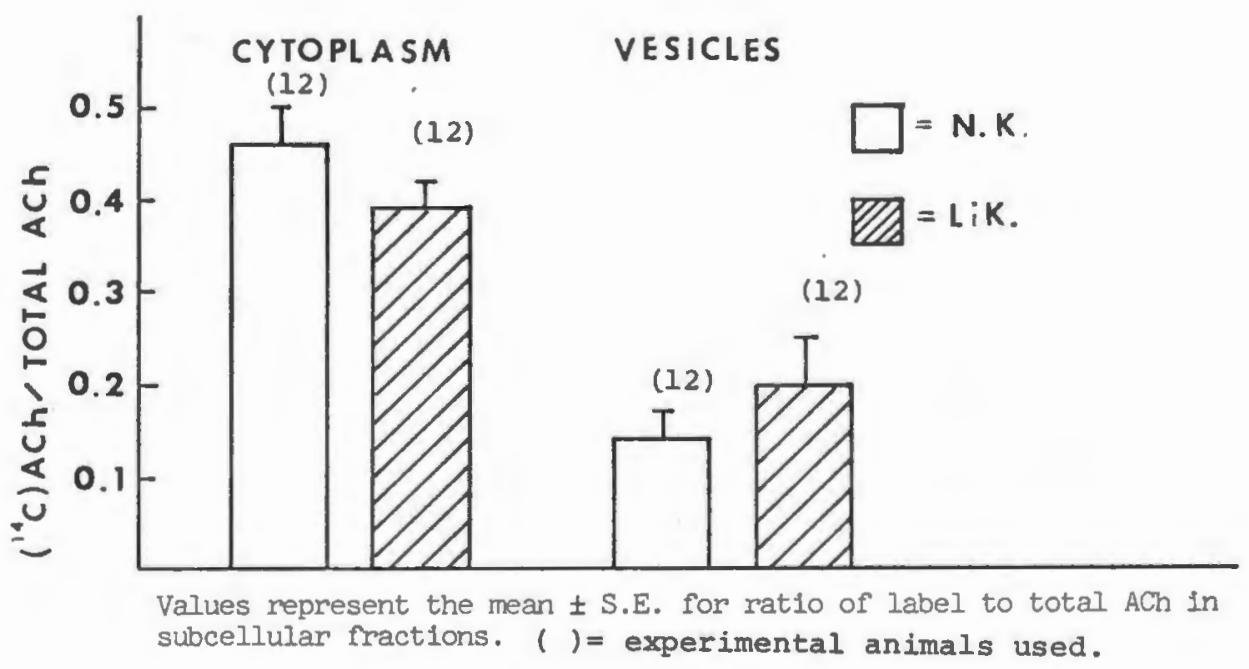


FIGURE V

INCUBATION IN N.K. WITH $100 \mu \mathrm{M}\left[{ }^{14} \mathrm{C}\right]$ Ahc SUBSEQUENT TO INCUBATION IN N.K. OR L.K.

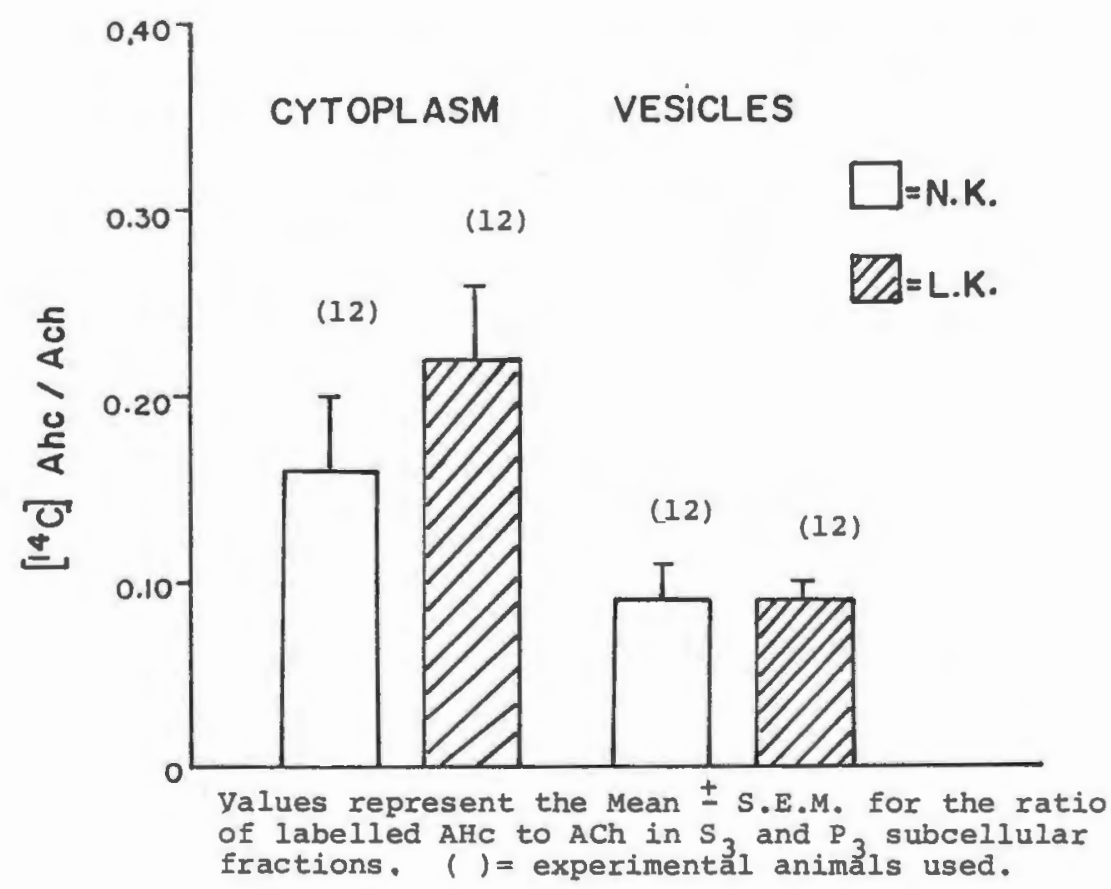




\section{REFERENCES}

Aquilonius, S.M., Flentge, F., Schuberth, J., Spart, B., and Sundwal1, A.: Synthesis of acetylcholine in different compartments of brain nerve terminals in vivo as studied by the incorporation of choline from plasma and the effect of pentobarbital on this process. J. Neurochem. 20: $1509-1521,1973$.

Barker, L.A. and Mittag, T.W.: Comparative studies of substances and inhibitors of choline transport and choline acetyltransferase. J. Pharmacol. Exp. Therap. 192: $86-94,1975$.

Barker, L.A., Dowdall, M.J. and Whittaker, V.P.: Chol ine metabolism in the central cortex of guinea pigs: Stablebound acetylcholine: Biochem. J. 130: 1063-1080, 1972.

Bhatnagar, S.P. and MacIntosh, F.C.: Effects of quaternary bases and inorganic cations on acetylcholine synthesis in nervous tissue. Can. J. Physiol. Pharmacol. 45: $249-268,1967$.

Bradford, H.F.: Respiration in vitro of synaptosomes from mammalian cerebral cortex. J. Neurochem. 16: 675-684, 1969.

Browning, E.T. and Schulman, M.P.: $\left[{ }^{14}\right.$ C]acetylcholine synthesis by cortex slices of rat brain. J. Neurochem. 15: $1391-1405,1968$.

Browning, E.T.: Free choline formation by cerebral cortical slices from rat brain. Biochem. Biophys. Res. Comm. 45: $1586-1590,1971$.

Canzanelli, A., Rogers, G. and Rapport, D.: Effects of inorganic ions on the respiration of brain cortex: 309315,1942 .

Carroll, P.T. and Goldberg, A.M.: Relative importance of choline transport to spontaneous and potassium depolarized release of acetylcholine. J. Neurochem. 25: 523$527,1975$.

Carroll, P.T. and Goldberg, A.M.: Biochemical evidence that the calcium-dependent potassium-induced release of acetylcholine from mouse brain is vesicular. J. Neurochem. Manuscript. 
Carroll, P.T. and Nelson, S.H.: Cholinergic vesicles: ability to empty and refill independently of cytoplasmic acetylcholine. Science 199: 85-86, 1978.

Chakin, L.W. and Whittaker, V.P.: The subcellular distribution of $\left[\mathrm{E}-\mathrm{Me}-{ }^{3} \mathrm{H}\right]$ acetylcholine synthesized by brain in vivo. Biochem. J. 113: 97-107, 1969.

Collier, B.: The preferential release of newly synthesized transmitter by a sympathetic ganglion. J. Physiol. 205: $341-352,1969$.

Collier, B., Poon, P. and Salehmoghadden, S.: The formation of choline and of acetylcholine by brain in vitro.

J. Neurochem. 19: 51-60, 1972 .

Collier, B. and Ilson, D.: The effect of preganglionic nerve stimulation on the accumulation of certain analogues of choline by a sympathetic ganglion. J. Physiol. 264: 489-509, 1977.

Collier, B., Lovat, S., Ilson, L.D., Barker, L.A. and Mittag, T.W.: The uptake, metabolism and release of homocholine: studies with rat brain synaptosomes and cat superior cervical ganglion. J. Neurochem. 28: 331-339, 1977.

Currier, S.F. and Mautner, H.G.: On the mechanism of action of choline acetyltransferase. Proc. Nat. Acad. Sci. U.S.A. 71: 3355-3358, 1974 .

Davis, K.L., Berger, P.A. and Hollister, L.E.: Choline for tardive dyskinesia. New England J. Med. 293, 1975.

Del Castillo, J. and Katz, B.: J. Physiol. Lond. 124: 560573,1954 .

Del Castillo, J. and Katz, B.: Local activity at depolarized nerve-muscle junction. J. Physiol. 128: 396-411, 1955.

Del Castillo, J. and Katz, B.: La Basi 'quantale' de la transmission neuromusculaire. In Microphysiologie Comparee des Elements Excitables. Coll. Internat. C.N.R.S., Paris, No. 67, 245-258, 1957.

DeRobertis, E.D.P. and Bennett, H.S.: Submicroscopic vesicular component in the synapse. Fed. Proc. 13: 35, 1954.

DeRobertis, E.D.P. and Bennett, H.S.: Some features of the submicroscopic morphology of synapses in frog and earth worm. J. Biophys. Biochem. Cytol. 1: 47-58, 1955. 
DeRobertis, E.D.P., Rodriguez De Lores Arnaiz, G., Saliganicoff, L., Peligrino, De Iraldi, A. and Zieher, L.M.: Isolation of synaptic vesicle and structural organization: the acetylcholine system within brain nerve endings. J. Neurochem. 10: 225-235, 1963.

Diamond, I. and Kennedy, E.P.: Carrier-mediated transport of choline into synaptic nerve endings. J. Biol. Chem. 244: $3258-3263,1969$.

Dowdal1, M.J. and Simon, E.J.: Comparative studies on synap-

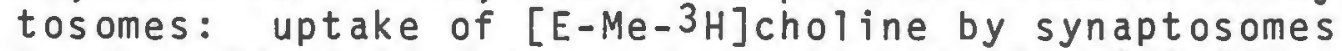
from squid optic lobes. J. Neurochem. 21: 969-982, 1973.

Dross, K. and Kewitz, H.: Concentration and origin of choine in the rat brain. Nauyn-Schmiedeberg's Arch. Pharmacol. 274: 91-100, 1972.

Eckernas, S-V.: Plasma choline and cholinergic mechanisms in the brain. Methods, functions, and role in Huntington's chorea. Acta Physiologica Scandinavica Supplementum 449: 1977 .

Fatt, P. and Katz, B.: Some observations on biological noise. Nature, 166:597-598, 1950.

Fatt, P. and Katz, B.: Spontaneous subthreshold activity at motor nerve endings. J. Physiol. 117: 109-128, 1952.

Feiganson, M.E. and Barnett, R.J.: Combined pharmacological and fine-structural studies of choline-0-acetyltransferase junction. Brain Res. 119: 155-179, 1977.

Fonnum, F.: The "compartmentation" of choline acetyltransferase within the synaptosome. Biochem. J. 103: 262270 , 1967.

Fonnum, F.: Choline acetyltransferase binding to and release from membranes. Biochem. J. 109: 389-3908, 1968.

Fonnum, F.: Isolation of choline esters from aqueous solutions by extraction with sodium tetraphenylboron in organic solvents. Biochem. J. 113: 291-298, 1969.

Fonnum, F.: Surface charge of choline acetyltransferase from different species. J. Neurochem. 17: 1095-1100, 1970.

Fonnum, F.: Recent developments in biochemical investigations of cholinergic transmission. Brain Res. 62: 497-507, 1973 . 
Goldberg, A.M. and McCaman, R.E.: The determination of picomole amounts of acetylcholine in mammalian brain.

J. Neurochem. 20: 1-8, 1973.

Gray, E.G. and Whittaker, V.P.: The isolation of nerve endings from brain: an electron microscopic study of cell fragments derived by homogenization and centrifugation. J. Anat. $96: 79-87,1962$.

Grewool, D.S. and Quastel, J.H.: Control of synthes is and release of radioactive acetylcholine in brain slices from the rat: effects of neurotropic drugs. Biochem. J. 132: 1-14, 1973 .

Hattori, T., Singh, V.K., McGeer, E.G. and McGeer, R.L.: Immunohistochemical localization of choline acetyltransferase containing neostriatal neurons and their relationship with dopaminergic synapses. Brain Res. 102: 164$173,1976$.

Haubrich, D.R. and Chippendale, T.J.: Regulation of acetylcholine synthesis in nervous tissue. Life Sci. 20: $1465-1478,1977$.

Hebb, C.0. and Whittaker, V.P.: Intracellular distribution of acetylcholine and choline acetyltransferase. J. Physiol. 142: 187-196, 1958.

Hebb, C.0. and Smallman, B.N.: Intracellular distribution of choline acetylase. J. Physiol. (Lond) 134:385-392, 1956 .

Hebb, C.0.: Biosynthesis of acetylcholine in nervous tissue. Physiol. Rev. 52: 918-957, 1972.

Heuser, J.E., Reese, T.S., Dennis, M.J., Jan, Y., Jan., L., and Evans, L.: J. Cell Biol. 81: 275-300, 1979.

Heuser, J.: Quick freezing evidence in favor of the vesicular hypothesis. Trends in Neuroscience 80-82, 1978.

Israel, M. and Dunant, Y.: Dynamics of acetylcholine compartments at rest and during nerve activity. In Metabolic Compartmentation and Neurotransmission Ed. Clarke, B.S. and Schneider, D. Plenum Press, p. 621, 1975.

Jenden, D.J., Choi, L., Silverman, R.W., Steinborn, J.A., Roch, M., Booth, R.A.: Acetylcholine turnover estimation in brain by gas chromatography/mass spectrometry. Life Sci. 14: 55-61, 1974. 
Jenden, D.J., Jope, R.S., and Wiler, M.H.: Regulation of acetylcholine synthesis. Does cytoplasmic acetylcho1 ine control high affinity choline uptake? Science $194: 635-637,1976$.

Jope, R.S.: Effects of lithium treatment in vitro and in vivo on acetylcholine metabolism in rat brain. J. Neurochem. 33: 487-495, 1979.

Kadota, K., Kadota, T. and Kamiya, Hiro-0.: Distribution of choline and acetylcholine in coated vesicles and plain synaptic vesicles. Brain Res. 76: 367-370, 1974.

Katz, B.: The release of transmitter substances. Springfield: Charles C. Thomas, 1969.

Katz, B. and Miledi, R.: A study of spontaneous miniature potentials in spinal motorneurons. J. Physiol. 168: $389-422,1963$.

Katz, B. and Miledi, R.: The timing of calcium action during neuromuscuiar transmission. J. Physiol. 189: 535$544,1967$.

Katz, B. and Miledi, R.: J. Physiol. 216:503-512, 1971.

Katz, H.S., Salehmoghaddam, S. and Collier, B.: The accumulation of radioactive acetylcholine by a sympathetic ganglion and by brain: failure to label endogenous stores. J. Neurochem. 20: 569-579, 1973.

Keynes, R.D. and Swan, R.C.: J. Physiol. (Lond) 147:626 (1959).

Krnjevick, K. and Phillis, J.W.: Acetylcholine sensitive cells in the cerebral cortex. J. Physiol. (Lond) 166: 296-326, 1963 .

Kuhar, M.J., Sethy, V.H., Roth, R.H. and Aghajanian, G.K.: Choline: selective accumulation by central cholinergic neurons. J. Neurochem. 20: 581-593, 1973.

Kuhar, M.J. and Simon, J.R.: Acetylcholine uptake: 1ack of association with cholinergic neurons. J. Neurochem. 22: $1135-1137,1974$.

Marchbanks, R.M.: Converstion of ${ }^{14} \mathrm{C}$ choline to ${ }^{14} \mathrm{C}$ acetylcholine by rat brain synaptosomes. Biochem. J. 100: $65-68,1966$.

Marchbanks, R.M.: Exchangeability of radioactive acetylcholine with the bound acetylcholine of synaptosomes and synaptic vesicles. Biochem. J. 106: 87-95, 1968. 
Marchbanks, R.M. and Israe 1, M.: The heterogeneity of bound acetyicholine and synaptic vesicles. Biochem. J. 129: $1049-1061,1972$.

McCamen, R.E. and Hunt, J.M.: Microdetermination of choline acetylase in nervous tissue. J. Neurochem. 12: 253-259, 1965.

McCamen, R.E. and Goldberg, A.M.: The determination of picomole amounts of acetyicholine. J. Neurochem. 20: 1-8, 1973.

McCamen, R.E. and Stetzler, J.: Radiochemical assay for acetylcholine: modification for sub-picomole measurements. J. Neurochem. 28: 669-671, 1977.

Miledi, R.: Transmitter release induced by injection of calcium ions into nerve terminals. Proc. Roi. Soc. London Ser. B. 183: 421-425, 1973 .

Nelson, S.H., Benishin, C.B., and Carroll, P.T.: Accumulation and metabolism of choline and homocholine by mouse brain subcelluiar fractions. Biochem. Pharmacol. 29: 1949$1957,1980$.

Nordberg, A.: Apparent regional turnover of acetylcholine in mouse brain. Methodological and functional aspects. Acta Physiol. Scand. Supp 1. 445: 1-5 T, 1977.

Potter, L.T.: Uptake of choline by nerve endings isolated from rat cerebral cortex. In: The interaction of drugs and subceliuiar components in an imal celTs. Campbell, P.N. ed. Litt Te-Brown and Co., 293-304, 1968.

Richter, J.A. and Marchbanks, R.M.: Synthesis of radioactive acetylcholine from ${ }^{3} \mathrm{H}$ choline and its release from cerebral cortex slices in vitro. J. Neurochem. 18: $691-703,1971$.

Robertson, J.D.: The ultrastructure of a reptilian myoneural junction. J. Biophys. Biochem. Cytol. 2: 381-394, 1956.

Salehmoghaddam, S.H. and Collier, B.: The relationship between acetylcholine release from brain slices and the acetylcholine content of subcellular fractions prepared from brain. J. Neurochem. 27: 71-76, 1976.

Schou, M.: The biology and pharmacology of the lithium ion. Pharmacological Rev. 9: 17, 1957.

Schuberth, J., Sundwal1, A., Sorbo, B., Lindell, J-0. Uptake of choline by mouse brain slices. J. Neurochem. 13: $347-352$, 1966 . 
Schuberth, J., Sparf, B. and Sundwall, A.: A technique for the study of acetylcholine turnover in mouse brain in vivo. J. Neurochem. 16:695-700, 1960.

Schuberth, J.M., Sparf, B. and Sundwall, A.: On the turnover of acetylcholine in nerve endings of mouse brain in vivo. J. Neurochem. 17: 461-468, 1970.

Simon, J.R., Atweh, S. and Kuhar, M.J.: Sodium-dependent high affinity choline uptake: a regulatory step in the synthesis of acetylcholine. J. Neurochem. 26: 909-922, 1976.

Simon, J.R. and Kuhar, M.J.: High affinity choline uptake: ionic and energy requirements. 'J. Neurochem. 27: 93-99, 1976 .

Smith, C.P. and Carroll, P.T.: A comparison of solubilized and membrane bound forms of choline-0-acetyltransferase (E.C. 2.3.1.6) in mouse brain nerve endings. Brain Res. 185: $363-371,1980$.

Somogyi, G.T. and Szerb, J.C.: Demonstration of acetylcholine release by measuring efflux of labelled choline from cerebral cortical silices. J. Neurochem. 19: 2667$2677,192$.

Spyker, J.M., Sparber, S.B. and Goldberg, A.M.: Subtle consequences of methyl-mercury exposure: behavior deviation in offspring of treated mothers. Science 177: $627-623,1972$.

Luskin, J.B.: Acetyicholine translocation in synaptic vesicle ghosts in vitro. J. Neurochem. 27: 853-857, 1976.

Luskin, J.B., Zimmerman, H., Whittaker, V.P.: Vesicular storage and release of acetylcholine in Torpedo electroplaque synapses. J. Neurochem. 30: 1269-1280, 1978.

Tauc, L., Hoffman, A., Tsuji, S., Hinzen, D.H., and Faille, L.: Transmission abolished on a cholinergic synapse after injection of acetylcholinesterase into the presynaptic neuron. Nature (Lond) 250: 496-498, 1974.

Toru, M. and Aprison, M.H.: Brain acetylcholine studies: A new extraction procedure. J. Neurochem. 13: 1533$1544,1966$.

von Schwarzenfeld, I.: Origin of transmitters released by electrical stimulation from a small, metabolically very active vesicular pool of cholinergic synapses in guinea pig cerebral cortex. Neuroscience 4: 477-493, 1979 . 
Whittaker, V.P.: The isolation and characterization of acetylcholine containing particles from brain. Biochem. J. 72: 694-706, 1959 .

Whittaker, V.P., Michaelson, I.A. and Kirkland, R.J.: The separation of synaptic vesicles from nerve ending particles (synaptosomes). Biochem. J. 90: 293-303, 1964.

Whittaker, V.P. and Sheridan, M.N.: Morphology and acetylcholine content of isolated cerebral cortical synaptic vesicles. J. Neurochem. 12: 363-372, 1965.

Whittaker, V.P. and Dowdal1, M.J.: Current state of research on cholinergic synapses. In: Cholinergic Mechanisms ed. Waser, P.G. Raven Press, p. 23-42, 1975.

Zimmerman, H. and Whittaker, V.P.: Effect of electrical stimulation on the yield and composition of synaptic vesicles from the cholinergic synapses of the electric organ of Torpedo: a combined biochemical, electrophysiological and morphological study. J. Neurochem. 22: $435-450,1974$.

Zimmerman, H. and Denston, C.R.: Separation of synaptic vesicles of different functional states from the cholinergic synapses of the Torpedo electric organ. Neuroscience 2: 715-730, 1977. 